University of Rhode Island

DigitalCommons@URI

Civil \& Environmental Engineering Faculty

Publications

Civil \& Environmental Engineering

2021

\title{
Versatility, Cost Analysis, and Scale-up in Fluoride and Arsenic Removal Using Metal-organic Framework-based Adsorbents
}

Linisha Biswal

Joseph E. Goodwill

University of Rhode Island, goodwill@uri.edu

Christoph Janiak

Somak Chatterjee

Follow this and additional works at: https://digitalcommons.uri.edu/cve_facpubs

The University of Rhode Island Faculty have made this article openly available.

Please let us know how Open Access to this research benefits you.

This is a pre-publication author manuscript of the final, published article.

Terms of Use

This article is made available under the terms and conditions applicable towards Open Access

Policy Articles, as set forth in our Terms of Use.

Citation/Publisher Attribution

Biswal, L., Goodwill, J. E., Janiak, C., \& Chatterjee, S. (2021). Versatility, Cost Analysis, and Scale-up in Fluoride and Arsenic Removal Using Metal-organic Framework-based Adsorbents. Separation \& Purification Reviews. DOI: 10.1080/15422119.2021.1956539 Available at: https://doi.org/10.1080/ 15422119.2021.1956539

This Article is brought to you for free and open access by the Civil \& Environmental Engineering at DigitalCommons@URI. It has been accepted for inclusion in Civil \& Environmental Engineering Faculty Publications by an authorized administrator of DigitalCommons@URI. For more information, please contact digitalcommonsgroup@uri.edu. 
Versatility, cost analysis, and scale-up in fluoride and arsenic removal using metalorganic framework based adsorbents

Linisha Biswal $^{\mathrm{a}}$, Joseph E. Goodwill ${ }^{\mathrm{b}}$, Christoph Janiak ${ }^{\mathrm{c}}$, Somak Chatterjee ${ }^{\mathrm{a} *}$

aDepartment of Chemical Engineering, Birla Institute of Technology and Science-Pilani, Pilani, Rajasthan, India.

${ }^{\mathrm{b}}$ Department of Civil and Environmental Engineering, University of Rhode Island, Kingston, Rhode Island, United States of America.

'Institute of Inorganic and Structural Chemistry, Heinrich-Heine-Universität Düsseldorf, 40204 Düsseldorf, Germany.

* Corresponding author:

Tel: + 01596-51-5757

Fax: + 91-1596-244183

Email - somak.chatterjee@pilani.bits-pilani.ac.in 


\begin{abstract}
Inorganic contaminants, such as fluoride and arsenic are problematic inorganic contaminants due to major human health risk and relatively high levels of occurrence. Metal-organic frameworks, (MOFs) are a novel approach to adsorption of fluoride and arsenic that have a high surface area, versatile building blocks and numerous active sites. This article presents a comprehensive review on different types of MOFs for fluoride and arsenic removal along with dynamic breakthrough time and cost analysis. Performances of MOFs are based on a variety of synthesis method, notable among which is solvothermal synthesis. However, it is evident from all the research conducted that MOFs have poor yield compared to conventional adsorbents. But, their high adsorption capacity, tailored chemical structure and ionic uptake of fluoride and arsenic makes them more favourable option than the other adsorbents. Material price of different MOFs usually varies between 0.1-5 $\mathrm{bSD} / \mathrm{gram}$, which is shown in this study.
\end{abstract}

Keywords: Metal-organic framework, MOFs; adsorption; arsenic removal; fluoride removal; fixed bed sorption; cost analysis 


\section{Contents}

\begin{tabular}{|c|c|c|c|}
\hline 1 & \multicolumn{2}{|c|}{ Introduction } & 3 \\
\hline 2 & \multicolumn{2}{|c|}{$\begin{array}{l}\text { Contamination of groundwater by fluoride and arsenic and related side- } \\
\text { effects }\end{array}$} & 4 \\
\hline \multirow[t]{2}{*}{3} & \multicolumn{2}{|c|}{$\begin{array}{l}\text { Conventional removal methods for the decontamination of fluoride and } \\
\text { arsenic ions from aqueous environment }\end{array}$} & 6 \\
\hline & 3.1 & Adsorption & 8 \\
\hline 4 & \multicolumn{2}{|c|}{ Superiority of MOFs in fluoride and arsenic adsorption } & 13 \\
\hline \multirow[t]{4}{*}{5} & \multicolumn{2}{|c|}{ Preparation of different varieties of MOFs } & 15 \\
\hline & 5.1 & Structure & 15 \\
\hline & 5.2 & Synthesis & 16 \\
\hline & 5.3 & Classifications & 17 \\
\hline \multirow[t]{4}{*}{6} & \multicolumn{2}{|c|}{ Different MOF based adsorbents for fluoride and arsenic uptake } & 17 \\
\hline & 6.1 & Uptake mechanism & 18 \\
\hline & 6.2 & Usage in fixed bed column study & 20 \\
\hline & 6.3 & $\begin{array}{l}\text { Cost analysis of MOFs used in fluoride and arsenic } \\
\text { removal }\end{array}$ & 21 \\
\hline 7 & \multicolumn{2}{|c|}{ Conclusion } & 22 \\
\hline 8 & \multicolumn{2}{|c|}{ Nomenclature } & 22 \\
\hline
\end{tabular}




\section{Introduction}

Water is an important concern, globally. Water stress has increased because of heavy agricultural and industrial demand, and changes in hydrologic cycles driven by climate change [1]. It is estimated that agricultural and energy water demand will continue to increase between $60 \%-80 \%$ for the agricultural and energy production activities by 2025 , while the rise in human population is expected in the range of $22-32 \%$ by $2050[2,3]$. Pollution of surface and groundwater remains a problem as well. Uncontrolled release of chemicals to the environment such as heavy metals, organics, inorganics, and fertilizers have deteriorated water quality [4, 5]. Some inorganic contaminants are persistent and usually well removed by conventional water treatment methods. Amongst these inorganic contaminants, fluoride (existing as $\mathrm{F}^{-}$) and arsenic (existing as arsenite, $\mathrm{AsO}_{3}{ }^{3-}$ and arsenate $\mathrm{AsO}_{4}{ }^{5-}$ ) are harmful and extensively found in groundwater. Pollution related to fluoride and arsenic occurs via geologic weathering and anthropogenic activities [6,7]. Fluorides contamination effects an estimated 62 million people, and 300 million are impacted by arsenic contaminated water [8]. Continuous consumption of fluoride and arsenic causes health problems, such as fluorosis, keratosis of hands and feet, hyperpigmentation, cancerous outgrowths in kidney, lungs, bladder, skin and liver [9, 10]. Therefore, it is necessary in many situations to remove fluoride and arsenic to provide safe drinking water.

Mitigative options for arsenic and fluoride treatment exist including electrocoagulation [11], precipitation [12], floatation [13], anion exchange [14], filtration with nanofiltration (NF) and reverse osmosis (RO) membranes [15, 16], electro-dialysis [17] and adsorption [18]. However, these methods have some potential drawbacks. For example, precipitation method produces toxic by-products, requiring removal prior to final adsorption [19], flotation requires substantial quantity of flocculating agents [20], regeneration in ion exchange carries brine disposal issues [21, 22] and fouling problems exist in NF and RO membranes [16, 23]. 
Adsorption with porous materials is another option for removal of arsenic and fluoride from potable water, offering relative ease in operation but with competition from other co-occurring adsorbates [24].

Metal-organic frameworks (MOFs) offer a potential alternative method from adsorption of fluoride and arsenic. MOFs have high surface area with abundant active sites for adsorption, as compared to other conventional adsorbents [25]. They also possess ordered crystalline structure, made of organic-inorganic hybrid networks [26]. MOFs are also known to exhibit superior physicochemical characteristics with varied adsorption applications, such as, uptake of hydrogen [27], carbon dioxide [28] and other toxic gases [29]. Due to their promising potential in these areas, researchers have started to investigate the capability of MOFs in removal of metal ions [30], as well as toxic dyes [31], herbicides [32] and humic acid [33] from groundwater. In general, MOFs have an adaptable and porous structure, allowing diffusion of ionic contaminants into their bulk structure [34]. Various studies reveal that certain MOFs show excellent uptake capacities. MOFs have also been evaluated for fluoride and arsenic (As(III) and As(V)) removal from groundwater. It was observed that MOFs exhibit high uptake capacity for fluoride $(32 \mathrm{mg} / \mathrm{g})$ and arsenic $(12 \mathrm{mg} / \mathrm{g})[35,36]$. The adsorptive properties of MOFs have further been enhanced by various chemical and structural modifications. The aim of this review is to provide an in-depth analysis about the latest development of MOFs related to fluoride and arsenic removal from groundwater. This work also presents the adsorption kinetics of selected MOFs in the dynamic purification of fluoride and arsenic contaminated streams via an empirical model along with its cost estimation.

\section{Contamination of groundwater by fluoride and arsenic and related side-effects}

A large section of the global population depends on groundwater as their primary source of water [37]. However, groundwater contamination by fluoride and arsenic leads to chronic poisonings and endemic diseases in some of these individuals. Mobilization of these two toxic 
contaminants under natural conditions is one of the main reasons for groundwater contamination [38].

The primary anthropogenic cause of fluoride pollution is mining and fertilizers production, especially, phosphate fertilizers. The element fluorine usually exists as fluorides in nature. It occurs mainly as magnesium fluoride (sellaite $-\mathrm{MgF}_{2}$ ), calcium fluoride (fluorspar $-\mathrm{CaF}_{2}$ ), sodium hexafluoroaluminate (cryolite $\left.-\mathrm{Na}_{3} \mathrm{AlF}_{6}\right)$ and fluoropartite $\left(\mathrm{Ca}_{5}\left(\mathrm{PO}_{4}\right)_{3} \mathrm{~F}\right)$ [39]. Depending on the $\mathrm{pH}$ of the medium, fluoride ion can form soluble complexes with polyvalent cations such as aluminium $\left(\mathrm{Al}^{3+}\right)$, magnesium $\left(\mathrm{Mg}^{2+}\right)$, calcium $\left(\mathrm{Ca}^{2+}\right)$ and iron $\left(\mathrm{Fe}^{3+}\right)$ [40]. Consumption of water containing excess of fluoride has profound negative effects on hydroxyapatite, $\left(\mathrm{Ca}_{5}\left(\mathrm{PO}_{4}\right)_{3} \mathrm{OH}\right)$ which is a mineral constituent of teeth and bones. Fluoropartite enhances density and hardness of teeth and bones, thereby making it brittle [10]. This condition is termed as fluorosis. Dental fluorosis usually occursin children when they chronically ingest fluoride-contaminated water [41]. However, skeletal fluorosis results in crippled anatomical structures mostly in adults. Apart from dental and skeletal fluorosis, fluoride exposure affects structure and functioning of skeletak muscle, brain and spinal cord and alters metabolism of essential nutrients. This leads to physical conditions such as hyperkalaemia, hypocalcaemia, hypomagnesemia and hypophosphatemia $[42,43]$. Considerable range of $0.5-1.5 \mathrm{mg} / \mathrm{L}$ fluoride in water is good for the health of teeth and bones, while the maximum limiting concentration of fluoride in water, suggested by the WHO, is $1.5 \mathrm{mg} / \mathrm{L}$ [44]. Maximum contaminant level (MCL) of fluoride enforced by the USEPA is $4.0 \mathrm{mg} / \mathrm{L}$ [45].

Arsenic is mobilized by volcanic emissions, biological activities, natural geochemical reactions, and anthropogenic causes. The dissolved and suspended forms of arsenic released by soil erosions and leaching, contribute to $612 \times 10^{8}$ and $2380 \times 10^{8} \mathrm{~g} / \mathrm{year}$, respectively [46]. Arsenic usually exists as arsenite $\left(\mathrm{AsO}_{3}{ }^{3-}\right)$ and arsenate $\left(\mathrm{AsO}_{4}{ }^{5-}\right)$ forms in natural waters, which are commonly referred to as $\mathrm{As}(\mathrm{III})$ and $\mathrm{As}(\mathrm{V})$. $\mathrm{As}(\mathrm{OH})_{3}$ undergoes protonation $\left(\mathrm{p} K_{\mathrm{a}}=\right.$ 
9.2); hence $\mathrm{As}(\mathrm{III})$ exists mainly in the form of uncharged arsenous acid $\left(\mathrm{H}_{3} \mathrm{AsO}_{3}\right)$ in contaminated stream. On the other hand, $\operatorname{As}(\mathrm{V})$ exists as oxyanions in the forms of arsenic acid, $\mathrm{H}_{2} \mathrm{AsO}_{4}^{-}\left(\mathrm{p} K_{\mathrm{a}}-2.3\right)$ and $\mathrm{HAsO}_{4}{ }^{2-}\left(\mathrm{p} K_{\mathrm{a}}-7.1\right)$ in oxidizing waters ( $\mathrm{pH}$ ranging from 6.58.5). Pentavalent species are stable in aerobic environments, while the trivalent arsenite are present in moderately reducing anaerobic environments [47]. Long term exposure of arsenic in drinking water, causes cancer of the skin, lung, bladder, and kidney. These are augmented with pigmentation changes, hyperkeratosis, myocardial infection, hypertension, diabetes, neurological disorders, muscular weakness, loss of appetite and nausea [9, 48]. Chronic exposure to arsenic results in Bowen's disease, characterized by inflammation of stomach and intestines, fatigue, kidney degeneration, bone-marrow degeneration, cirrhosis of the liver, and severe dermatitis. It is observed that arsenic shares many properties with tumour promoters, by activating transcription factors, intracellular signal transduction and changing expression of genes that are involved in promoting cell growth $[49,50]$. A WHO provisional guideline of 10 $\mu \mathrm{g} / \mathrm{L}$ of arsenic has been adopted as the drinking water standard in many areas. However, some countries have retained the earlier standard of $50 \mu \mathrm{g} / \mathrm{L}$ [51]. The USEPA MCL for arsenic is $0.010 \mathrm{mg} / \mathrm{L}[52]$.

\section{Conventional removal methods for the decontamination of fluoride and arsenic ions from aqueous environment}

Techniques such as, precipitation, coagulation or electrocoagulation, membrane filtration and adsorption are mostly used to treat water contaminated with fluoride and arsenic. Discussions related to each removal method along with their advantages and disadvantages are described in the following section. A summary of different methods for fluoride and arsenic uptake with the specific agent used in the process, has been presented in Table 1 [Table 1 near here]. 
Studies such as a two-column limestone reactor [13], crushed limestone [53], co-precipitation with calcium enhanced ferric hydroxides [54] and calcium phosphate hydroxyapatite [55] were reported for fluoride and arsenic removal by precipitation method. It was concluded from these studies that this method was relatively easy in operation but its major disadvantages were initial cost and sludge disposal. Similarly, both electrocoagulation and chemical coagulation have been examined for fluoride and arsenic removal. For example, defluoridation was investigated using a continuous flow electrocoagulation reactor [56], parallel-plate electro-coagulation process [57] and a natural coagulant Moringa oleifera (MO) [58]. While arsenic removal was studied in a mine drainage system using coarse calcite coated ferric sulphate [59], electrocoagulation using mild and stainless plates [60] and aluminium alloy and stainless-steel electrodes [61]. The studies suggested the process to be both eco-friendly and cost-effective option for municipal and industrial water treatment, but requires continuous addition of substantial quantities of coagulants and further sludge treatment.

Membrane separation techniques such as reverse osmosis (RO), Nanofiltration (NF) and electro-dialysis (ED) are commonly used for fluoride and arsenic removal. The feasibility of applying RO membranes to process electronic industrial effluent with a load of one $\mathrm{kg} / \mathrm{day}$ of fluoride [62], portable ultra-low-pressure RO system (ULPRO) to remove fluoride and total dissolved solids (TDS) from coalbed methane (CBM)-produced water [63] and removal of arsenic using seawater high rejection (SWHR) and brackish water (BW-30) membranes [64] have been reported. In these studies, main focus was on RO process. In another study fluoride removal from a high fluoride stream was studied using negatively charged commercial thinfilm composite (TFC) membranes [65], flat sheet crossflow NF module was utilised for fluoride removal from contaminated groundwater [66] and arsenic removal by commercial TFC membrane $[67,68]$ were reported. Fluoride removal from aqueous solution was studied by electro-dialysis, using TS-1-10 (Tokuyama) electro-dialysis equipment [69], SB-6407 anion 
exchange membrane [70], corning P1 electro-dialysis pilot equipment [71], while for arsenic removal a laboratory-scale electrodialyzer [72] and BEL-500 stack [73] have been reported. In these studies, removal efficiency was better over precipitation and coagulation, but the major disadvantage of these processes is fouling and high cost.

\subsection{Adsorption}

Precipitation, coagulation, electrocoagulation and membrane separation successfully decrease fluoride and arsenic concentrations to acceptable levels; however, they have certain limitations. For example, precipitation and coagulation are economical, but they are known to produce a large amount of sludge that needs further treatment [19, 20]. Membrane separation processes are usually energy intensive, compared to conventional treatment [16, 23]. Adsorption offers critical advantages, such as robustness, lower operating cost, greater efficiency, and, most importantly, the possibility of using versatile adsorbent materials [24]. For example, activated carbons include a versatile range of carbonaceous adsorbents, which can be made to increase surface area andporosity. The use of activated carbon dates back to ancient times, while its current usage for water treatment has begun in the second half of the $20^{\text {th }}$ century [74]. Activated carbon is known to have strong affinity to these organic and inorganic contaminants, even at lower concentrations, thereby making it a high performance and low energy alternative. Adsorption has gained full-scale acceptance in fluoride and arsenic removal from industrial wastewater and groundwater.

It is well known that adsorption is a surface phenomenon, hence surface ions and $\mathrm{pH}$ play a vital role in the process. Adsorption mechanism [75] of fluoride ions on solid particles can be explained with the following steps: (1) mass transfer of fluoride ions from bulk stream to external surface of the adsorbent, known as external mass transfer; (2) adsorption of fluoride ions on the external surface of the particle; (3) transfer of the adsorbed fluoride ions to the internal surfaces of the porous material, i.e., intraparticle diffusion or possible exchange of 
adsorbed fluoride ions with structural elements inside the adsorbent. Removal of fluoride has been studied using different adsorbents. One such example is porous magnesium oxide $(\mathrm{MgO})$ nanoplates [76]. $\mathrm{pH}$ had a minimum effect in the range 2-11. However, when the $\mathrm{pH}$ exceeded 12, fluoride removal rate was decreased because hydroxyl ions compete with fluoride ions for adsorption sites in alkaline $\mathrm{pH}$, resulting in the reduction of fluoride removal percentage. A Fourier-transform infrared (FTIR) spectroscopy study suggested that total amount of carbonates on $\mathrm{MgO}$ decreased during fluoride adsorption process. It is well accepted that fluoride ions can be adsorbed on $\mathrm{MgO}$ surface via surface hydroxyl and carbonate exchange. Similar results were obtained from XPS, confirming that coexistence of bicarbonate and carbonate ions has an enormous impact on adsorption performance. The adsorption mechanism for fluoride removal was also investigated using zirconium oxide $\left(\mathrm{ZrO}_{2}\right)$ mesoporous fibers [77]. It was observed that $\mathrm{pH}$ substantially affected adsorption capacity. When the $\mathrm{pH}$ of the solution was below isoelectric point $(\mathrm{pH}=4)$ of $\mathrm{ZrO}_{2}$, hydroxyl groups on the surface of the fibers were protonated, resulting an increasé in active sites and reinforcing interaction between the adsorbent and fluoride. This contrasts with the surface of $\mathrm{ZrO}_{2}$ fibers carrying negative charges at high $\mathrm{pH}$, thereby repelling fluoride. Additionally, there was a decline in fluoride uptake capacity when the $\mathrm{pH}$ was reduced to 2 , which was due to sparingly soluble hydrofluoric acid formation. FTIR and XPS studies suggested an ion-exchange mechanism involved in fluoride adsorption, as shown below in Equation 1:

$-\mathrm{Zr}-\mathrm{OH}_{(S)}+F^{-}(\mathrm{L}) \rightarrow-\mathrm{Zr}-\mathrm{F}_{(S)}+\mathrm{OH}_{(L)}^{-}$

Yadav et al., also studied removal of fluoride from aqueous solution by three low-cost agricultural biomass-based adsorbents: wheat straw raw (WSR), sawdust raw (SDR) and activated bagasse carbon $(\mathrm{ABC})$ [78]. It was observed that $\mathrm{pH}$ and functional groups on the bio-sorbent played a major role in fluoride adsorption [79]. Maximum biosorption values were observed at acidic $\mathrm{pH}$, where overall surface charges are likely positive, enabling binding of 
negatively charged fluoride ions. At lower $\mathrm{pH}$, surface of adsorbent turned out to be positively charged while relative sorption inhibition was observed at basic $\mathrm{pH}$ attributing to increase in hydroxyl ion and the formation of aqua complexes. From the kinetic study, the dual nature of the adsorption isotherms support that the initial curve is due to the boundary layer diffusion, while the final linear portion is due to intraparticle diffusion. This indicated that the mechanism of fluoride removal was complex. Hence, both surface adsorption and intraparticle diffusion contributed to the rate determining step. Defluoridation of water was also investigated using pine wood and pine bark-based biochar and it was prepared by pyrolysis at $400^{\circ} \mathrm{C}$ and $450^{\circ} \mathrm{C}$ in a reactor [80]. As-synthesized chars were characterized and used for defluoridation of acidic groundwater. Swelling of the chars was observed attributable to increased oxygen percentage which subsequently opened new internal pores within the Sample. This lead to diffusion of fluoride ions into the subsurface, thereby promoting further adsorption. Ion exchange was observed as the mode of uptake. The authors further concluded that these chars could have been tested for activation and enhancement of surface area for increased uptake, as they had greater ability to remove higher fluoride content than activated carbon. Similarly, activated carbon were prepared from bark of Morinda tinctoria coated with aluminium hydroxide [81]. Industrial bone char [82] and bone char from Pleco fish (Pterygoplichthys spp.) [83] were also used for fluoride uptake. Similar studies were performed with metal activated carbon [84], rice husk [85], bael shell [86], calcium chloride modified Crocus sativus leaves [87]. These are all natural products which were physically and chemically activated. Tri-metal oxide and rare earth minerals were also used for activation. For example, Mg-Mn-Zr impregnated activated carbon [88], cerium impregnated activated carbon-based novel composite [89] have been reported. These studies revealed that adsorption was primary mechanism for uptake, where surface charges, $\mathrm{pH}$, ion exchange, intraparticle diffusion, electrostatic attraction/repulsion were important factors, as explained above. 
Removal of arsenic was also conducted by different adsorbents. For example, arsenic removal by feldspar was studied, concluding that both electrostatic forces and chemical interactions were the adsorption mechanisms [90]. The positively charged surface of the mineral is obtained when $\mathrm{pH}$ is lower than the point of zero charge $\left(\mathrm{pH}_{\mathrm{PZC}}\right)$ of the sorbent, leading to more favourable adsorption of $\mathrm{As}(\mathrm{V})$. Surface ionization reactions occur, depending on $\mathrm{pH}$ of the solution containing the mineral. Surface protonation (Equation 2) is promoted in acidic medium, whereas, deprotonation reaction (Equation 3) is increased under basic conditions, as shown below:

$\mathrm{Al}_{s}-\mathrm{OH}+\mathrm{H}^{+} \leftrightarrow \mathrm{Al}_{s}-\mathrm{OH}_{2}^{+}$

$A l_{s}-O H \leftrightarrow A l_{s}-O^{-}+H^{+}$

where $\mathrm{Al}_{s}-\mathrm{OH}$ is neutral aluminol, $\mathrm{Al}_{s}-\mathrm{OH}_{2}{ }^{+}$is protonated aluminol, $\mathrm{Al}_{s}-\mathrm{O}^{-}$is hydrolysed aluminol and $\mathrm{H}^{+}$is proton or hydrogen ion.

Both the positively charged surface of solid (aluminol active sites present as $\equiv \mathrm{Al}-\mathrm{OH}^{+}$) and the predominant speciation of $\mathrm{H}_{2} \mathrm{AsO}_{4}{ }^{-}$are favourable for $\mathrm{As}(\mathrm{V})$ uptake at acidic condition. However, adsorption of monodentate hon-ionized arsenite (As(III)) was contrary to As(V), occurring only through a ligand exchange reaction and, most favourably, onto the non-ionized surface functional groups. The authors concluded that coulombic interaction and solution $\mathrm{pH}$ is practically insignificant for $\mathrm{As}(\mathrm{III})$ adsorption as compared to $\mathrm{As}(\mathrm{V})$. Arsenic removal was also studied using iron oxide modified thermally produced cigarette soot activated carbon (CSAC) i.e. $\left(\mathrm{Fe}_{3} \mathrm{O}_{4} / \mathrm{CSAC}\right)$ adsorbent [91]. In this study, it was observed that arsenic adsorption was highly $\mathrm{pH}$ dependent. $\mathrm{pH}_{\mathrm{pzc}}$ of the adsorbent decreased as arsenic anions make the surface charge more negative. It was evident from FTIR studies that removal of hydroxyl functional groups from adsorbent surface took place, generating complexes such as As(III) $\mathrm{Fe}_{3} \mathrm{O}_{4} / \mathrm{CSAC}$ and $\mathrm{As}(\mathrm{V})-\mathrm{Fe}_{3} \mathrm{O}_{4} / \mathrm{CSAC}$. This confirmed a possible mechanism of monodentate and bidentate ligand exchange for arsenic. In case of arsenate adsorption, protonated hydroxyl 
groups electrostatically attracted $\mathrm{As}(\mathrm{V})$ species (i.e., $\mathrm{H}_{2} \mathrm{AsO}_{4}{ }^{-}$) in acidic solution, forming monodentate and bidentate complexes, between the $\mathrm{M}-\mathrm{OH}$ groups. Arsenite, being present in uncharged form in neutral $\mathrm{pH}\left(\mathrm{pH}\right.$ 7), gets adsorbed on $\mathrm{Fe}_{3} \mathrm{O}_{4} / \mathrm{CSAC}$ surfaces by forming monodentate complexes. Arsenic removal was also investigated using magnetic biochar [92]. Results demonstrated that adsorption of $\mathrm{As}(\mathrm{V})$ on the biochar $/ \gamma-\mathrm{Fe}_{2} \mathrm{O}_{3}$ composite was relatively fast and reached equilibrium within four hours. This rapid kinetics suggested that biochar might play an important role in the dispersion of $\gamma-\mathrm{Fe}_{2} \mathrm{O}_{3}$ particles, which increased the surface area of particles and active sites of metal oxides. A similar kinetic study also suggested that adsorption of $\mathrm{As}(\mathrm{V})$ to metal oxide surfaces is mainly through surface complexation reactions and can be described by one and two-site models. Monodentate and bidentate As(V) adsorption reactions can be written as follows:

Monodentate: $\mathrm{SOH}+\mathrm{H}_{3} \mathrm{AsO}_{4} \leftrightarrow \mathrm{SH}_{m} \mathrm{AsO}_{4}^{(m-2)}+(2 \tau m) \mathrm{H}^{+}+\mathrm{H}_{2} \mathrm{O}$

Bidentate: $\quad \mathrm{S}(\mathrm{OH})_{2}+\mathrm{H}_{3} \mathrm{AsO}_{4} \leftrightarrow \mathrm{SH}_{n} \mathrm{AsO}_{4}{ }^{(n-d)}+(1-n) \mathrm{H}^{+}+\mathrm{H}_{2} \mathrm{O}$

where $S$ is $\gamma-\mathrm{Fe}_{2} \mathrm{O}_{3}, m$ having a value of 0,1 or 2 and $n$ can be 0 or 1 .

These adsorption reactions were observed to be monolayer and site-limited and thus confirmed to Langmuir adsorption theory. A microporous activated carbon was prepared for arsenic removal from water [93]. Surface functionality of iron loaded activated carbon (FCAC) is highly $\mathrm{pH}$ dependent and affects arsenic adsorption on its surface. Positive charge on the surface is converted to negative charge by deprotonation due to abundance of hydroxyl ion at higher $\mathrm{pH}$. On the other hand, negatively charged species faces electrostatic repulsion, which is attributed to its lower adsorption, in addition to higher number of organic functional groups, which are randomly distributed on the chemical activated carbon (CAC) surface than that of physical activated carbon (PAC). It was also observed that CAC adsorbed iron species, thereby decreasing pore size. In arsenic uptake, micropores and surface functional groups played significant roles, as CAC performed much better than PAC. However, none of them produced 
the desired separation of arsenic from water. In contrast, FCAC could achieve the desired uptake of arsenic due to iron, which produced a strong affinity between surface functional groups and arsenic species. Similarly, other adsorbents such as Sargassum muticum coated with iron-oxy(hydroxides) [94], iron hydroxide/manganese dioxide doped straw activated carbon [95], Perilla leaf biochar [96], Japanese oak wood biochar [97] are few examples of natural adsorbents that have been physically and chemically activated. In some studies, rare earth metals were used for activation. For example, cerium oxide modified activated carbon [98], $\mathrm{CeO}_{2} / \mathrm{Fe}_{2} \mathrm{O}_{3} /$ graphene nanocomposite [99] and Halloysite- $\mathrm{CeO}_{\mathrm{x}}(\mathrm{x}=1.5-2.0)$ nanocomposite [100] have been reported. Similar studies were performed using iron for impregnation. For example, magnetic gelatin modified biochar [101], $\mathrm{Fe}_{3} \mathrm{O}_{4} @ \mathrm{Al}_{2} \mathrm{O}_{3} @ \mathrm{Zn}-\mathrm{Fe}$ LDH (LDH - layered double hydroxides) [102] and iron-incorporated activated carbon from biomass mixture [103] have been reported. Modifications were also done using mesoporous bismuth-impregnated aluminum oxide [104]; aluminum-based adsorbent and coal mine drainage sludge coated polyurethane [105] and covalent triazine framework encapsulated $\gamma$ $\mathrm{Fe}_{2} \mathrm{O}_{3}$ nanoparticles [106]. These studies revealed that adsorption mechanism was mainly dominated by monodentate and bidentate complex formation and electrostatic attraction or repulsion. Table 2 summarises list of adsorbents for fluoride and arsenic uptake with their respective adsorption capacities and mechanism. [Table 2 near here]

\section{Superiority of MOFs in fluoride and arsenic adsorption}

As outlined in Section 3, various approaches have been adopted for defluoridation and arsenic removal from groundwater. Precipitation [13, 55], electrocoagulation [57, 60], membrane separation $[62,69]$ and adsorption techniques $[76,85]$ are some of the most common and efficient methods for the same. Recently, MOFs have drawn increased research interest because of their unique properties. They are made of organic and inorganic material and possess crystalline structure, have a large internal surface area (more than $6000 \mathrm{~m}^{2} / \mathrm{g}$ ), as well 
as high thermal and chemical stability with high porosity (greater than $80 \%$ ) [26]. These MOFs consist of a positively charged metal ion surrounded by an organic linker, forming a cage-like hybrid structure. MOFs have some inherent advantages, compared to other porous materials in terms of atomic-level structural uniformity, tuneable porosity, uniform pore structures, flexible network topology and other chemical and geometric identities [25, 26].

Researchers have started to explore the use of MOFs in water treatment and have observed some promising results [30]. Several research articles have been published (approximately 1500) related to MOFs for water treatment. Few of them have been cited here as an example for examining MOFs to mitigate metal ions [30], dyes [31] and herbicides [32]. These studies suggest that different MOFs are stable in various aqueous solutions, and exhibit relatively high contaminant removal. Recently, MOFs have also been examined for fluoride and arsenic removal $[35,36]$. Table 3 summarizes the adsorption capacities of various MOFs that are utilized for fluoride and arsenic uptake. If is evident that MOFs exhibit high adsorption capacity for these ions, compared to other adsorbents. For example, alumina treated activated carbon has a fluoride adsorption capacity of $4.5 \mathrm{mg} / \mathrm{g}$ [84], while that of aluminium fumarate MOF is $600 \mathrm{mg} / \mathrm{g}$ [108]. This MOF has similar chemical composition to the conventional adsorbent, but a much greater defluoridation capacity is due to its large surface area (1156 $\mathrm{m}^{2} / \mathrm{g}$ ). With respect to arsenic sorption, zirconium-based nanoparticle doped activated carbon fibers have a reported uptake capacity of $21 \mathrm{mg} / \mathrm{g}$ [101], while that of zirconium MOF is 303 $\mathrm{mg} / \mathrm{g}$ [109]. However, surface area of the former is observed to be higher. Zirconium based activated carbon fibers have surface area of $1409 \mathrm{~m}^{2} / \mathrm{g}$, while that of zirconium MOF is 570 $\mathrm{m}^{2} / \mathrm{g}$. The authors cited that high uptake capacity for MOF can be then attributed probably to its internal cage structure. Constricted chains in the cage structure perhaps results in lower surface area. But this cage structure provides more space to uptake of fluoride than conventional adsorbents. Detailed discussion regarding their preparation routes, 
characterization, uptake capacities and mechanism have been performed in the next sections, which highlight superior performance of MOFs as compared to traditional sorbents.

\section{Preparation of different varieties of MOFs}

\subsection{Structure}

MOFs are composed of different unit types: (1) secondary building units (SBUs), which are essentially a cluster of metal ions, and (2) organic linkages between subsequent SBUs that gives rise to highly porous crystalline structure. The organic units are typically mono, di, tri or tetravalent ligands. The choice of metal and linker decide the structure and properties of MOF. For instance, the metal coordination preference impacts size and shape of pores. This coordination also controls the number of ligands binding to the metal along with its orientation. SBUs are attached by the bridging ligands. Typical bridging ligands are di and tricarboxylic acids. Examples are benzene-1,4-dicarboxylic acid (BDC) or terephthalic acid and biphenyl4,4'-dicarboxylic acid (BPDC) [110]. [Figure 1 near here]

Figure 1 shows SBU (metal node) and organic linker used for synthesis of IRMOF - 1 (IR Isoreticular) and HKUST-1(Hong Kong University of Science and Technology) [111]. The combination of these structures results in a large number of possible arrangements. MOFs can also be synthesized using same SBU, but different organic linkers [112], as shown in Figure 2. [Figure 2 near here]. Diverse pore shapes can be obtained depending on the linker. Figure 3 shows representative SBUs and organic linkers used for synthesis of MOFs [113]. SBUs has served as an organizing concept for classification of MOFs structures into their underlying topology. They are also essential to design the directionality of MOFs construction and achieve robust frameworks. It also ensures thermodynamic, mechanical and, architectural stability, originating from strong directional bonds, thereby locking down the position of metal centres [114] [Figure 3 near here] 


\subsection{Synthesis}

Figure 4 summarises commonly used synthesis methods for MOFs. Usually, MOFs are prepared by mixing metal salts, organic ligands and solvent for specific time duration (usually between 12 and 48 hours) [25]. The product formed from the reaction is then filtered and dried. A common synthesis method of MOFs is hydrothermal or solvothermal synthesis [115]. Generally, high-solubility organic solvents, such as dimethyl-formamide, ethanol, acetonitrile, methanol and acetone are used in solvothermal reactions. Mixtures of various solvents can be used to avoid problems, related to solubility of initial reagents. Solvothermal synthesis is generally performed in Teflon-lined autoclaves at temperatures higher than $130^{\circ} \mathrm{C}$ [115]. [Figure 4 near here].

Other synthesis routes such as microwave-assisted, electrochemical, sonochemical, mechanochemical and spray-drying have been a focus of recent research. Solid state-based synthesis method of MOFs also exists [116]. No external energy supply is required in this method. This route collectively uses different solvents to increase solubility of the reagents and accelerate synthesis by rapid eyaporation of solvents. These methods can synthesize a greater quantity of MOFs in a smaller period of time [117]. Thermodynamic and activation energy of the synthesizing reaction is based on the redox potential, reactivity and solubility of the solvent. Microwave-assisted synthesis provides advantage of short synthesis time, porous texture, reduced particle size, better morphology and high crystallinity, compared to solvothermal method. However, this method is solvent sensitive as it involves interaction of the solvent with electromagnetic and electrical waves [118]. Mechanochemical synthesis works on mechanical agitation and collision between substances. This mechanochemical approaches offers the advantages of process efficiency, simplicity, no solvent usage and low energy consumption [119]. Intensive ultrasonic radiation $(20 \mathrm{kHz}-10 \mathrm{MHz})$ is applied in sonochemical synthesis producing cavitation-the generation of small bubbles within liquid 
phase. Produced bubbles collapse momentarily creating localized moments of high temperature and pressure. These ephemeral areas generate homogenous nucleation centres that decrease crystallization time as compared to more conventional solvothermal methods [120]. Electrochemical synthesis produces MOFs using thin films over surfaces at mild temperatures, reducing the effect of film cracking of metal salts in the solution, while offering its continuous production. Electrochemical synthesis is important from industrial process perspective as it offers continuous production of MOFs [121]. Figure 5 summarises such methods with reaction temperatures and final reaction products in MOF synthesis [122]. [Figure 5 near here].

\subsection{Classifications}

Crystal engineering of MOFs not only relies on permanent porosity, but also on other factors post-modification including reversible structural transformation, and framework integrity. In this context, an attributive classification of MOFs helps in understanding their structure. As depicted in Figure 6, first generation MOFs have only non-permanent porosity because of inseparable host-guest dependence. This phenomenon has often been observed in MOFs containing charged frameworks, with pores filled by counter anions. Comparatively, second generation MOFs possess stable and robust porosity against guest removal such as in neutral and zeolite-like MOFs. Third generation MOFs display framework flexibility and dynamics, and are able to respond to guest exchange or external stimuli. Fourth generation MOFs are correlated to recently developed post-synthetic modifications (PSM) and may be broadly defined as post-processing MOFs. They can maintain underlying topology and structural integrity towards various PSM [123]. [Figure 6 near here]

\section{Different MOF based adsorbents for fluoride and arsenic uptake}

Different studies have been performed to explore the utility of MOFs as an efficient adsorbent for water treatment. For example, MOFs have been utilized for heavy metals removal [30] and dyes [31]. Different aspects including the uptake mechanism usage in fixed bed 
columns for dynamic operations and the manufacturing cost have been discussed in the following sections.

\subsection{Uptake mechanism}

Different MOFs and their respective uptake mechanisms are summarised in Table 3. It is usually observed that intraparticle diffusion [124] and the specific nature of surface ions [125] govern the adsorption mechanism in MOFs. Figure 7 depicts the possible uptake mechanisms for adsorptive removal [126]. Defluoridation mechanism was studied using water stable MOFs [127]. Eleven water-stable MOFs, MIL-53 (containing, iron, chromium and aluminium, MIL - Matériaux de 1'Institut Lavoisier), MIL-68 (containing aluminium), aluminium based MOFs (CAU-1, CAU-6), UiO-66 (zirconium and hydrofluoric acid) and ZIFs-7, 8, 9 (zeolitic imidazole framework) were consideredin this case. It was concluded from performed characterizations that certain best practices should be observed to design MOFs with better stability in fluoride spiked aqueous solution. For example, a relatively inert metal can be better choice for MOFs with the same topology [127]. In the same study, pore topology was considered for materials with same metal cluster. It was also suggested that coordination number of metals should be high and appropriate hydrophobicity can lead to good stability of MOFs. The authors used UiO-66(Zr) for removal of fluoride from water because of higher adsorption capacity. Defluoridation capacity of MOFs are dependent on concentration of other co-existing ions in the solution. Also, increasing the number of hydroxyl groups is an efficient strategy to improve MOF performance. From the kinetic study, it was observed that mechanism of fluoride adsorption on $\mathrm{UiO}-66(\mathrm{Zr})$ is complex and both surface adsorption and intraparticle diffusion contribute to rate-determining step [127]. It was also suggested that fluoride ions are adsorbed onto $\mathrm{UiO}-66(\mathrm{Zr})$, as its pore size is larger than ionic radius of fluoride. Two lanthanide-based MOFs were prepared and investigated for removal of fluoride from water [128]. Adsorption was facilitated at lower $\mathrm{pH}(3-7)$, but it dropped drastically after $\mathrm{pH} 8$. At 
lower $\mathrm{pH}$, lanthanide-based MOFs are positively charged and nucleophilic replacement of hydroxyl ions by fluoride essentially uninhibited. However, many MOFs decompose in a very acid medium, and at $\mathrm{pH} \leq 2$ most $\mathrm{MOF}$ s have negligible adsorption effectiveness. Nucleophilic replacements are not preferred at higher $\mathrm{pH}$ because of abundance of hydroxyl ions, which competes with fluoride for the active sites in the adsorbent. Therefore, it is apparent that adsorption of fluoride from aqueous media is best carried out at $\mathrm{pH}$ ranging from 3 to 7 . Similar to previous studies, zirconium-MOF [129], UiO-66- $\mathrm{NH}_{2}$ [130], MOF - 801 [131], calcium fumarate $(\mathrm{CaFu})$ [132] and UiO-66-amine [133] were mostly dominated by surface ion exchange and intraparticle diffusion mechanism for fluoride adsorption. [Table 3 near here]

The removal of arsenic from aqueous solution using ZIF-8 MOF [134] was studied. The $\mathrm{pH}_{\mathrm{ZPC}}$ of ZIF-8 MOF was 9.6 and this is stable at neutral and basic conditions. In acidic conditions, ZIF-8 MOF dissolves in the stream which dramatically hinders adsorption of arsenic. An intraparticle diffusion model was used to analyse rate-controlling step, based on the kinetics data in order to identify arsenic transport process across ZIF-8 MOF. The authors concluded from kinetic studies that adsorption rates were mainly controlled by pore diffusion rather than mass transfer through boundary layer. Zn-MOF-74 was also utilized for ultra-trace quantity arsenic removal [135]. Maximum removal of $\mathrm{As}(\mathrm{V})$ was achieved at $\mathrm{pH}$ 6-8. Adsorption mechanism was due to electrostatic interaction or chemical reaction between the arsenate and functional groups on the surface of Zn-MOF-74. It was concluded that adsorption of arsenate onto this adsorbent was due to chemical interactions, leading to substitution of water molecules inside pore channels. It was also observed that intraparticle diffusion is the rate controlling step during this process. Similarly, other MOFs, such as, AUBM-1 (AUBM: American University of Beirut Materials) [136], $\mathrm{NH}_{2}-\mathrm{MIL}-88(\mathrm{Fe})$ [137], MIL-53(Fe) [138], MIL-101(OH) 3 and MIL-101(OH) [139], MOF-808 [140], MIL-53(Al) [141], ZIF-8 [142], UiO-66 incorporated thin nanocomposite membrane [143], $\mathrm{Fe}_{3} \mathrm{O}_{4} @ \mathrm{MIL}-101$ [144], ZIF-8 
(cetyltrimethylammonium bromide (CTAB) and amino acid L-histidine (His) as co-templates) [145] and BUC - 17 [146] were reported for arsenic adsorption. These MOFs are influenced by electrostatic, acid-base and coordination interactions, along with hydrogen bonding.

\subsection{Usage in fixed bed column study}

It is known that data obtained from batch studies are usually limited to laboratory scale. Complication are incurred in employing MOFs at full-scale. Column studies become necessary to obtain data for design of continuous flow sorption model [147]. Various MOFs have higher adsorption capacity compared to conventional adsorbents. Hence, it becomes important to test the MOFs in a continuous flow operation. Most of the research articles concerning MOFs for water treatment did not portray fixed bed column studies. Hence, in this article, we have estimated the breakthrough time for continuous flow operation by using sorption data from batch studies and few assumptions. These assumptions are (a) packed bed containing $5 \mathrm{~kg}$ MOF as adsorbent; (b) packed bed can treat $40 \mathrm{~L}$ /day of feed solution and (c) feed solution have fluoride and arsenic concentration $\left(C_{o}\right)$ of $10 \mathrm{mg} / \mathrm{L}$ and $5 \mathrm{mg} / \mathrm{L}$, respectively.

An empirical model, i.e., Thomas model [148] has been used to estimate breakthrough time of these MOFs in fixed-bed adsorption column. Linearized form of this model can be described by the following expression,

$\ln \left(\frac{C_{t}}{C_{o}}-1\right)=\frac{k_{T H} q_{e} m}{Q}-k_{T H} C_{o} t$

where, $k_{T H}$ is Thomas model constant $(\mathrm{mL} / \mathrm{min} \mathrm{mg}), q_{e}$ is adsorption capacity $(\mathrm{mg} / \mathrm{g}), C_{o}$ is effluent concentration $(\mathrm{mg} / \mathrm{L}), m$ is adsorbent dosage $(\mathrm{g}), Q$ is feed flowrate $(\mathrm{mL} / \mathrm{min}), \mathrm{t}$ is breakthrough time $(\mathrm{min})$. Thomas model constant, $k_{T H}$ has values in the range $0.08-0.03$ $\mathrm{mL} / \mathrm{min} \mathrm{mg}$ for most adsorbents in reported articles [149]. An average value of $0.051 \mathrm{~mL} / \mathrm{min}$ mg for Thomas model constant, $k_{T H}$ has been chosen in this article. Breakthrough time have been calculated for different adsorbents, related to arsenic and fluoride removal. These values are presented in the Table 4. It is observed in Table 4 that calcium fumarate MOF [132] will 
show maximum breakthrough time ( 25 hours) to produce filtrate, having fluoride concentration lesser than allowable limit (1.5 mg/L), while MOF - 801 [131] attains the lowest one (6 hours). Similarly, maximum breakthrough time having arsenic concentration lesser than $10 \mu \mathrm{g} / \mathrm{L}$ will be attained for $\mathrm{Zr}-\mathrm{MOF}$ (UiO-66) (44 hours) [109] while the lowest one by MIL- 53(Fe) (6 hours) [138]. These studies suggest that the prepared MOFs can be utilized for continuous flow operations, which can later be scaled up to a community-based filter. [Table 4 near here].

\subsection{Cost analysis of MOFs used in fluoride and arsenic removal}

Cost analysis of MOFs is necessary to assess the financial costs and/or benefits resulting from full-scale adaptation. A detailed cost analysis of MOFs is provided in Table 4. Table 4 includes results of a lanthanide-based MOF utilized for defluoridation, which cost approximate 1 USD/gram to manufacture [128]. MOF cost is inherently material dependent. For example, the cost of zirconium MOF [129] is observed to be an order of magnitude lower than the lanthanide-based example (0.1 USD/gram vs. $1 \mathrm{USD} / \mathrm{gram})$. In the arsenic removal context, the cost of BUC-17 [146] MOF is the highest (5 USD/gram), while zirconium MOF [109] is the lowest (0.2 USD/gram). It is usually observed that the range of the manufacturing cost for one gram of MOF lies within 0.1 USD-5 USD. One can assume a median value of 2.5 USD per gram of MOF as its manufacturing cost, while the cost of other components to fabricate a filter is 45 USD. Hence, if $50 \mathrm{~kg}$ of a generic MOF is required to produce safe drinking water, then the total cost of the medium and the filter accessories can be calculated to be as 170 USD (rounded of to $150 \mathrm{USD}$ ). Most of the commercially available filters have a price ranging from 200-250 USD, where they claim to remove arsenic and fluoride from drinking water [143]. Therefore, based on the estimated cost, MOF based filter seems a frugal option. 


\section{Conclusions}

The current review gives a broader picture of water treatment via MOFs, focused on removal of fluoride and arsenic. Different remedial measures have been adopted to remove these persistent pollutants from water. However, these methods have high operating cost or they produce toxic sludge, which requires further treatment. On the other hand, MOFs are novel adsorbents, which have high uptake capacity for fluoride and arsenic and they can counter the disadvantages of conventional adsorbents to a great extent. Synthesis routes and building blocks can be altered, giving rise to versatile class of MOFs. However, MOFs remain restricted to lab-scale usage and are not explored for continuous flow sorption. MOFs based filter can be a cost-effective option in comparison to conventional filters, as shown in this study. However, low yield percentage of MOFs can be a blockade in their path for commercialization. The article also presents the breakthrough times of these MOFs in fixed bed adsorption columns, based on empirical mathematical model. Manufacturing cost of different MOFs along with filter accessories, have been estimated andit shows that they can be hosted an alternative option to large scale water treatment, especially related to fluoride and arsenic removal.

\section{Nomenclature}

\section{Abbreviations}
$4-\mathrm{NP}$
4-nitrophenol

$\mathrm{ABC}$

activated bagasse carbon

AUBM

American University of Beirut Materials

$\mathrm{BDC}$ terepthalic acid/benzene-1,4-dicarboxylic acid

BET Brunauer-Emmett-Teller 


\begin{tabular}{|c|c|}
\hline BIB & bis-1H-imidazol-1-yl-methyl benzene \\
\hline BPY & 4,4'-bipyridine \\
\hline BUT & Beijing University of Technology \\
\hline $\mathrm{BW}-30$ & brackish water - 30 \\
\hline CBM & coalbed methane \\
\hline CNT & carbon nanotube \\
\hline $\mathrm{CP}$ & cycling properties \\
\hline CSAC & cigarette soot activated carbon \\
\hline CTAB & cetyltrimethylammonium bromide \\
\hline $\mathrm{CV}$ & cyclic voltammetry \\
\hline $\mathrm{DD}$ & desalination degree \\
\hline DPNI & N, N-di-(4-pyridyl)-1,4,5,8-naphthalene tetra-carboxy-di-imide \\
\hline DSLF & dual site Langmuir- Freundlich \\
\hline ED & electrodialysis \\
\hline EIS & electrochemical impedance spectroscopy \\
\hline FCAC & iron loaded activated carbon \\
\hline FS & flocculation - sedimentation \\
\hline FTIR & Fourier-transform infrared spectroscopy \\
\hline $\mathrm{H}_{2} \mathrm{BPDC}$ & 4,4'-biphenyl-dicarboxylic acid \\
\hline
\end{tabular}




\begin{tabular}{|c|c|}
\hline $\mathrm{H}_{3} \mathrm{TATB}$ & 4,4,4-s-triazine-2,4,6-triyl-tribenzoic acid \\
\hline HKUST -1 & Hong Kong University of Science and Technology \\
\hline HRT & hydraulic retention time \\
\hline IAST & ideal adsorption solution theory \\
\hline IRMOF & isoreticular metal organic framework \\
\hline IXED & ion exchange/electrodialysis \\
\hline $\mathrm{L}$ & liquid \\
\hline LDH & layered double hydroxides \\
\hline $\mathrm{LP}_{\mathrm{P}}$ & permeability \\
\hline MCL & maximum contaminant level \\
\hline MIL & Matériaux de l'Instifut Lavoisier \\
\hline MO & Moringa oleifera \\
\hline $\mathrm{MOF}$ & metal-organic framework \\
\hline MWCO & molecular weight cut-off \\
\hline NDC & 2,6-naphthalenedicarboxylate \\
\hline NF & nanofiltration \\
\hline NFT & nitrofurantoin \\
\hline NZF & nitrofurazone \\
\hline PAC & physical activated carbon \\
\hline
\end{tabular}




\begin{tabular}{|c|c|}
\hline $\mathrm{pH}$ PZC & point of zero charge \\
\hline PPCN & polyethylene-glycol citrate-co-N-isopropylacrylamide \\
\hline PSAC & palm shell activated carbon \\
\hline PSM & post synthetic modifications \\
\hline PTA & p-benzene-dicarboxylic acid \\
\hline $\mathrm{RO}$ & reverse osmosis \\
\hline ROS & reactive oxygen species \\
\hline $\mathrm{r}_{\mathrm{P}}$ & pore radius \\
\hline RPDA & photometric dispersion analysis 5 \\
\hline $\mathrm{S}$ & solid \\
\hline SAR & sodium adsorption ratio \\
\hline SBU & secondary building unit \\
\hline SDR & sawdust raw \\
\hline SWHR & seawater high rejection \\
\hline TAN & total ammonia nitrogen \\
\hline TDS & total dissolved solids \\
\hline $\mathrm{TFC}$ & thin-film composite \\
\hline TIPA & tris-4-imidazolyl-phenyl-amine \\
\hline TNP & 2,4,6-trinitrophenol \\
\hline
\end{tabular}




$\begin{array}{ll}\text { ULPRO } & \text { ultra-low-pressure reverse osmosis system } \\ \text { WHO } & \text { World Health Organisation } \\ \text { WSR } & \text { wheat straw raw } \\ \text { XPS } & \text { X-ray photoelectron spectroscopy } \\ \text { XRD } & \text { zeolitic imidazole framework } \\ \mathrm{ZIF} & \text { zinc oxide } \\ \mathrm{ZnO} & \text { zirconium oxide }\end{array}$

\section{Chemical formulae}

$\mathrm{Al}(\mathrm{OH})_{3}$

aluminium hydroxide

$\mathrm{Al}_{2}\left(\mathrm{SO}_{4}\right)_{3}$

aluminium sulphate

$\mathrm{Al}^{3+}$

aluminium cation

$\mathrm{Al}_{\mathrm{n}} \mathrm{F}_{\mathrm{m}}(\mathrm{OH})_{3 \mathrm{n}-\mathrm{m}}$

aluminium fluoride hydroxide complex

$\mathrm{Al}-\mathrm{OH}^{+}$

aluminol

$\mathrm{Al}_{\mathrm{s}}-\mathrm{O}^{-}$

hydroxylyzed aluminol,

$\mathrm{Al}_{\mathrm{s}}-\mathrm{OH}$

neutral aluminol

Als $-\mathrm{OH}_{2}^{+}$

protonated aluminol

As

arsenic

As(III)

arsenite 


\begin{tabular}{|c|c|}
\hline $\mathrm{As}(\mathrm{V})$ & arsenate \\
\hline $\mathrm{AsO}_{3}{ }^{3-}$ & arsenite \\
\hline $\mathrm{AsO}_{4}{ }^{5-}$ & arsenate \\
\hline $\mathrm{Ca}^{2+}$ & calcium cation \\
\hline $\mathrm{Ca}_{5}\left(\mathrm{PO}_{4}\right)_{3} \mathrm{~F}$ & fluorapatite \\
\hline $\mathrm{Ca}_{5}\left(\mathrm{PO}_{4}\right)_{3} \mathrm{OH}$ & hydroxyapatite \\
\hline $\mathrm{CAC}$ & chemical activated carbon \\
\hline $\mathrm{CaCO}_{3}$ & calcite \\
\hline $\mathrm{CaF}_{2}$ & calcium fluoride/fluorspar \\
\hline $\mathrm{CO}_{2}$ & carbon dioxide \\
\hline $\mathrm{Co}_{3} \mathrm{O}_{4}$ & cobalt $t$ \\
\hline $\mathrm{Cu}$ & copper \\
\hline $\mathrm{F}$ & fluoride \\
\hline $\mathrm{Fe}^{3+}$ & ferric/iron cation \\
\hline $\mathrm{Fe}_{3} \mathrm{O}_{4}$ & iron oxide \\
\hline $\mathrm{FeCl}_{3}$ & iron chloride \\
\hline $\mathrm{H}^{+}$ & hydrogen ion \\
\hline $\mathrm{H}_{2} \mathrm{AsO}_{4}^{-}$ & dihydrogen arsenate \\
\hline $\mathrm{H}_{3} \mathrm{AsO}_{3}$ & arsenous acid \\
\hline
\end{tabular}




$\begin{array}{ll}\mathrm{HAsO}_{4}^{2-} & \text { hydrogen arsenate } \\ \mathrm{Hg}^{2+} & \text { mercuric ion } \\ \left.\mathrm{Mg}^{2+} \mathrm{H}_{2} \mathrm{gal}\right) & \text { magnesium gallate } \\ \mathrm{Mg}^{2+} & \text { magnesium cation } \\ \mathrm{MgF}_{2} & \text { magnesium oxide } \\ \mathrm{MgO}^{2+} & \text { sodium hexafluoroaluminate/cryolite } \\ \mathrm{Na}_{3} \mathrm{AlF}_{6} & \text { nickel } \\ \mathrm{Ni} & \text { tin oxide } \\ \mathrm{NiO}^{-\mathrm{OH}} & \text { nickel oxide } \\ \mathrm{SnO} & \text { hydroxyl group } \\ & \end{array}$

Symbols

$C_{o}$ initial effluent concentration (mg/L or $\mu \mathrm{g} / \mathrm{L})$

$C_{t}$ final effluent concentration $(\mathrm{mg} / \mathrm{L}$ or $\mu \mathrm{g} / \mathrm{L})$

M adsorbent dosage (g)

$k_{T H}$ Thomas model constant (mL/min.mg)

$q_{e}$ adsorption capacity $(\mathrm{mg} / \mathrm{g})$

$Q$

flow rate $(\mathrm{mL} / \mathrm{min})$ 
Greek symbols

$\Psi$

constant surface electrical potential

\section{Conflict of Interest}

The authors declare that no conflict of interests exists in this review paper.

\section{Acknowledgements}

The review work is supported by research initiation grant offered to Dr. Somak Chatterjee, Department of Chemical Engineering, BITS Pilani, Pilani Campus and the research assistantship provided to Ms. Linisha Biswal by the BITS Pilani Institute. It is also a result of collaborative efforts between Dr. Somak Chatterjee, Dr. Joseph Goodwill and Dr. Christoph Janiak.

\section{Authors Responsibilities}

L. Biswal: Writing - Original Draft; Writing - Review \& Editing, Joseph. E. Goodwill: Writing - Review \& Editing, Christoph Janiak: Writing - Review \& Editing, Somak Chatterjee: Conceptualization, Writing - Review \& Editing; Supervision. 


\section{Reference}

[1] Gleick, P.H. Global Freshwater Resources: Soft-Path Solutions for the 21st Century. Science. 2003, 302, 1524-1528. https://doi.org/10.1126/science.1089967

[2] Edition, F. Guidelines for Drinking-water Quality. World Health, 2011. https://doi.org/10.1016/S1462-0758(00)00006-6

[3] The sustainable development goals report 2019. United Nations Publ. issued by Dep. Econ. Soc. Aff., 2019.

[4] Singh, Jyoti, Priyanka Yadav, Ashok Kumar Pal, and Vishal Mishra. Water pollutants: Origin and status. In Sensors in Water Pollutants Monitoring: Role of Material, pp. 5-20. Springer, Singapore, 2020. https://doi.org/10.1007/978-981-15-0671-0_2

[5] Srivastav, Arun Lal. Chemical fertilizers and pesticides: role in groundwater contamination. In Agrochemicals detection, treatment and remediation, pp. 143-159. Butterworth-Heinemann, 2020. https://doi.org/10.1016/B978-0-08-103017-2.00006-4

[6] Berg, M., and J. E. Podgorski. Groundwater Assessment Platform (GAP): A new GIS tool for risk forecasting and mitigation of geogenic groundwater contamination. In Environmental Arsenic in a Changing World: Rroceedings of the 7th International Congress and Exhibition on Arsenic in the Environment (AS 2018), July 1-6, 2018, Beijing, PR China, p. 5. CRC Press, 2019.https://doi.org/10.1201/9781351046633-2

[7] Alarcón-Herrera, M. T., Martin-Alarcon, D. A., Gutiérrez, M., Reynoso-Cuevas, L., Martín-Domínguez, A., Olmos-Márquéz, M. A., Bundschuh, J. Co-occurrence, possible origin, and health-risk assessment of arsenic and fluoride in drinking water sources in Mexico: Geographical data visualization. Sci. Total Environ. 2020, 698, 134168. https://doi.org/10.1016/j.scitotenv.2019.134168

[8] Jha, S. K., and V. K. Mishra. Fluoride and arsenic in groundwater: occurrence and geochemical processes controlling Mobilisation. In Innovative saline agriculture, pp. 351369. Springer, New Delhi, 2016. https://doi.org/10.1007/978-81-322-2770-0_16

[9] Mukherjee, A., Sengupta, M.K., Hossain, M.A., Ahamed, S., Das, B., Nayak, B., Lodh, D., Rahman, M.M., Chakraborti, D. Arsenic contamination in groundwater: a global perspective with emphasis on the Asian scenario. J. Health Popul. Nutr. 2006, 142-163. $\underline{10.3329 / \mathrm{jhpn} . \mathrm{v} 24 \mathrm{i} 2.727}$

[10] Brindha, K., and Elango, L. Fluoride in groundwater: causes, implications and mitigation measures. Fluoride properties, applications and environmental management, 2011, 1 111-136. $\quad$ https://www.novapublishers.com/catalog/productinfo.php?products id=15895

[11] Sandoval, M. A., Fuentes, R., Nava, J. L., Coreño, O., Li, Y., Hernández, J. H. Simultaneous removal of fluoride and arsenic from groundwater by electrocoagulation using a filter-press flow reactor with a three-cell stack. Sep. Purif. Technol., 2019, 208, 208-216. https://doi.org/10.1016/j.seppur.2018.02.018 
[12] Reardon, E. J., and Wang, Y. A limestone reactor for fluoride removal from wastewaters. Environ. Sci. Technol. 2000, 34, 3247-3253. https://doi.org/10.1021/es990542k

[13] Zhou, C. C., Liu, C., Zhang, N. N., Cong, L. F., Pan, J. H., Peng, C. B. Fluorine in coal: the modes of occurrence and its removability by froth flotation. Int. J. Coal Prep. Util. 2018, 38, 149-161. https://doi.org/10.1080/19392699.2016.1215312

[14] Guo, Q., and Tian, J. Removal of fluoride and arsenate from aqueous solution by hydrocalumite via precipitation and anion exchange. Chem. Eng. J., 2018, 231, 121-131. https://doi.org/10.1016/j.cej.2013.07.025

[15] Richards, L. A., Richards, B. S., Rossiter, H. M. A., Schäfer, A. I. Impact of speciation on fluoride, arsenic and magnesium retention by nanofiltration/reverse osmosis in remote Australian communities. Desalination, 2009, 248, 177-183. https://doi.org/10.1016/j.desal.2008.05.054

[16] Salazar, H., Nunes-Pereira, J., Correia, D.M., Cardoso, V.F., Gonçalves, R., Martins, P.M., Ferdov, S., Martins, M.D., Botelho, G., Lanceros-Méndez, S. Poly (vinylidene fluoride-hexafluoropropylene)/bayerite composite membranes for efficient arsenic removal from water. Mater. Chem. Phys. 2016, 183, 430-438. https://doi.org/10.1016/j.matchemphys.2016.08.049

[17] Bhadja, V., Trivedi, J. S., Chatterjee, U. Efficacy of polyethylene interpolymer membranes for fluoride and arsenic ion removal during desalination of water via electrodialysis. $R S C A d v$., 2016, 6, 67118-67126. https://doi.org/10.1039/C6RA11450D

[18] Li, W., Cao, C. Y., Wu, L. Y., Ge, M. F., Song, W. G. Superb fluoride and arsenic removal performance of highly ordered mesoporous aluminas. J. Hazard. Mater., 2011, 198, 143-150. https://doi.org/10.1016/j.jhazmat.2011.10.025

[19] Vázquez Mejía, G., Martínez-Miranda, V., Fall, C., Linares-Hernández, I., SolacheRíos, M. Comparison of Fe-Al-modified natural materials by an electrochemical method and chemical precipitation for the adsorption of $\mathrm{F}-$ and $\mathrm{As}(\mathrm{V})$. Environ. Technol. Inno. 2016, 5, 558-568. https://doi.org/10.1080/09593330.2015.1074724

[20] Mohora, E., Rončević, S., Dalmacija, B., Agbaba, J., Watson, M., Karlović, E., Dalmacija, M. Removal of natural organic matter and arsenic from water by electrocoagulation/flotation continuous flow reactor. J. Hazard. Mater., 2012, 235, $257-$ 264. https://doi.org/10.1016/j.jhazmat.2012.07.056

[21] Jamhour, R. M. A. Q. New inorganic ion-exchange material for the selective removal of fluoride from potable water using ion-selective electrode. Am. J. Environ. Sci., 2005, 1, 1-4. https://doi.10.3844/ajessp.2005.1.4

[22] Kim, J., and Benjamin, M. M. Modeling a novel ion exchange process for arsenic and nitrate removal. Water Res., 2004, 38, 2053-2062. https://doi.org/10.1016/j.watres.2004.01.012

[23] Durmaz, F., Kara, H., Cengeloglu, Y., Ersoz, M. Fluoride removal by Donnan dialysis with anion exchange membranes. Desalination, 2005, 177, 51-57. https://doi.org/10.1016/j.desal.2004.11.016 
[24] Tian, Y., Wu, M., Liu, R., Wang, D., Lin, X., Liu, W., Ma, L., Li, Y., Huang, Y. Modified native cellulose fibers-A novel efficient adsorbent for both fluoride and arsenic. J. Hazard. Mater., 2011, 185, 93-100. https://doi.org/10.1016/j.jhazmat.2010.09.001

[25] Hasan, Z., and Jhung, S. H. Removal of hazardous organics from water using metalorganic frameworks (MOFs): plausible mechanisms for selective adsorptions. J. Hazard. Mater., 2015, 283, 329-339. https://doi.org/10.1016/j.jhazmat.2014.09.046

[26] Yaghi, O. M., Li, G., Li, H. Selective binding and removal of guests in a microporous metal-organic framework. Nature, 1995, 378, 703-706. https://doi.org/10.1038/378703a0

[27] Bobbitt, N. S., and Snurr, R. Q. Molecular modelling and machine learning for highthroughput screening of metal-organic frameworks for hydrogen storage. Mol. Simulat. 2019, 45, 1069-1081. https://doi.org/10.1080/08927022.2019.1597271

[28] Li, T., Sullivan, J. E., Rosi, N. L. Design and preparation of a core-shell metal-organic framework for selective CO2 capture. J. Am. Chem. Soc. 2013, 135, 9984-9987. https://doi.org/10.1021/ja403008j

[29] Bobbitt, N. S., Mendonca, M. L., Howarth, A. J., Islamoglu, T., Hupp, J. T., Farha, O. K., Snurr, R. Q. Metal-organic frameworks for the removal of toxic industrial chemicals and chemical warfare agents. Chem. Soc. SRev. 2017, 46, 3357-3385. https://doi.org/10.1039/C7CS00108H

[30] Jayaramulu, K., Narayanan, R. P., George, S. J., Maji, T. K. Luminescent microporous metal-organic framework with functional lewis basic sites on the pore surface: specific sensing and removal of metal ions? Inorg. Chem. 2012, 51, 10089-10091. https://doi.org/10.1021/ic3017547

[31] Haque, E., Jun, J. W., Jhung, S. H. Adsorptive removal of methyl orange and methylene blue from aqueous solution with a metal-organic framework material, iron terephthalate (MOF-235) J. Hazard. Mater., 2011, 185, 507-511. https://doi.org/10.1016/j.jhazmat.2010.09.035

[32] Jung, B. K., Hasan, Z., Jhung, S. H. Adsorptive removal of 2, 4-dichlorophenoxyacetic acid (2, 4-D) from water with a metal-organic framework. Chem. Eng. J. 2013, 234, 99105. https://doi.org/10.1016/j.cej.2013.08.110

[33] Lin, K. Y. A., and Chang, H. A. Efficient adsorptive removal of humic acid from water using zeolitic imidazole framework-8 (ZIF-8). Water Air Soil Poll. 2015, 226, 10. https://doi.org/10.1007/s11270-014-2280-7

[34] Li, J., Wang, X., Zhao, G., Chen, C., Chai, Z., Alsaedi, A., Hayat, T., Wang, X. Metalorganic framework-based materials: superior adsorbents for the capture of toxic and radioactive metal ions. Chem. Soc. Rev. 2018, 47, 2322-2356. https://doi.org/10.1039/C7CS00543A

[35] Zhang, N., Yang, X., Yu, X., Jia, Y., Wang, J., Kong, L., Jin, Z., Sun, B., Luo, T., Liu, J. Al-1, 3, 5-benzenetricarboxylic metal-organic frameworks: A promising adsorbent for defluoridation of water with $\mathrm{pH}$ insensitivity and low aluminum residual. Chem. Eng. J. 2014, 252, 220-229. https://doi.org/10.1016/j.cej.2014.04.090 
[36] Zhu, B.J., Yu, X.Y., Jia, Y., Peng, F.M., Sun, B., Zhang, M.Y., Luo, T., Liu, J.H., Huang, X.J. Iron and 1, 3, 5-benzenetricarboxylic metal-organic coordination polymers prepared by solvothermal method and their application in efficient As (V) removal from aqueous solutions. J. Phys. Chem. C 2012, 116, 8601-8607. https://doi.org/10.1021/jp212514a

[37] World Health Organization. Progress on household drinking water, sanitation and hygiene 2000-2017: special focus on inequalities. World Health Organization, 2019.

[38] Chouhan, S., and Flora, S. J. Arsenic and fluoride: two major ground water pollutants. Indian J. Exp. Biol. 2010, 48, 666. http://nopr.niscair.res.in/handle/123456789/9735

[39] Edmunds, W. Mike, and Pauline L. Smedley. "Fluoride in natural waters." In Essentials of medical geology, pp. 311-336. Springer, Dordrecht, 2013. https://doi.org/10.1007/978-94-007-4375-5_13

[40] Agarwal, M., Rai, K., Shrivastav, R., Dass, S. Fluoride speciation in aqueous suspensions of montmorillonite and kaolinite. Toxicol. Environ. Chem. 2002, 82, 11-21. https://doi.org/10.1080/713746660

[41] Aoba, T., and Fejerskov, O. Dental fluorosis: chemistry and biology. Crit. Rev. Oral Biol. Med. 2002, 13, 155-170. https://doi.org/10.1177\%2F 154411130201300206

[42] Srivastava, S., and Flora, S. J. S. Fluoride in Drinking Water and Skeletal Fluorosis: A Review of the Global Impact. Curn Environ. Health Rep. 2020, 1-7. https://doi.org/10.1007/s40572-020-00270-9

[43] Nayak, B., Roy, M. M., Das, B., Pál, A., Sengupta, M. K., Prasad De, S., Chakraborti, D. Health effects of groundwater flutoride contamination. Clin. Toxicol. (Phila.), 2009, 47, 292-295. https://doi.org/10.1080٪15563650802660349

[44] Ali, S., Thakur, S. K., Sarkar, A., Shekhar, S.Worldwide contamination of water by fluoride. Environ. Chem. Lett. 2016, 14, 291-315. https://doi.org/10.1007/s10311-016$\underline{0563-5}$

[45] Senior, Lisa A., and Ronald A. Sloto. Arsenic, boron, and fluoride concentrations in ground water in and near diabase intrusions, Newark Basin, Southeastern Pennsylvania. No. 2006-5261. US Geological Survey, 2006. https://doi.org/10.3133/sir20065261

[46] Patel, K. S., Shrivas, K., Brandt, R., Jakubowski, N., Corns, W., Hoffmann, P. Arsenic contamination in water, soil, sediment and rice of central India. Environ. Geochem. Health. 2005, 27, 131-145. https://doi.org/10.1007/s10653-005-0120-9

[47] Garelick, H., Jones H., Dybowska A., Valsami-Jones. E. Arsenic pollution sources. Reviews of Environmental Contamination Volume $197(2009)$ : 1760.https://doi.org/10.1007/978-0-387-79284-2_2

[48] Ng, J. C., Wang, J., and Shraim, A. A global health problem caused by arsenic from natural sources. Chemosphere, 2003, 52, 1353-1359. 10.1016/S0045-6535(03)00470-3. 
[49] Huq, S. I., Joardar, J. C., Parvin, S., Correll, R., Naidu, R. Arsenic contamination in food-chain: transfer of arsenic into food materials through groundwater irrigation. J. Health Popul. Nutr. 2006, 24, 305. 10.3329/jhpn.v24i3.716

[50] Rahman, M. M., Ng, J. C., Naidu, R. Chronic exposure of arsenic via drinking water and its adverse health impacts on humans. Environ. Geochem. Health. 2009, 31, 189-200. https://doi.org/10.1080/09603120220129346

[51] Organization, W.H. (2010). Chemical fact sheets. Guidel. Drink.Organization

[52] Wang, L. K., Hung, Y. T., Shammas, N, K., eds. Physicochemical treatment processes. Vol. 3. Totowa, NJ: Humana Press, 2005.https://doi.org/10.1385/1-59259-820-x:141

[53] Turner, B. D., Binning, P. Stipp, S. L. S. Fluoride removal by calcite: evidence for fluorite precipitation and surface adsorption. Environ. Sci. Technol. 2005, 39, 9561-9568. https://doi.org/10.1021/es0505090

[54] Ruiping, L., Xing, L., Shengji, X., Yanling, Y., Rongcheng, W., Guibai, L. CalciumEnhanced Ferric Hydroxide Co-Precipitation of Arsenic in the Presence of Silicate. Water Environ. Res. 2007, 79, 2260-2264. https://doi.org/10.2175/106143007X199324

[55] Dungkaew, W., Haller, K.J., Flood, A.E., Scamehorn, J.F. Arsenic removal by precipitation with Calcium phosphate hydroxyapatite. In Advanced Materials Research, vol. 506, pp. 413-416. Trans Tech Publications Ltd, 2012. https://doi.org/10.4028/www.scientific.net/AMR.506.413

[56] Emamjomeh, M. M., and Sivakumar, M. Fluoride removal by a continuous flow electrocoagulation reactor. J. Environ. Manage. 2009, 90, 1204-1212. https://doi.org/10.1016/j.jenvman.2008.06.001

[57] Khatibikamal, V., Torabian, A., Janpoor, F., Hoshyaripour, G. Fluoride removal from industrial wastewater using electrocoagulation and its adsorption kinetics. J. Hazard. Mater. 2010, 179, 276-280. https://doi.org/10.1016/j.jhazmat.2010.02.089

[58] Jafari, A., Mahvi, A. H., Godini, H., Rezaee, R., Hosseini, S. S. Process optimization for fluoride removal from water by Moringa oleifera seed extract. Fluoride. 2014, 47, 15260 .

[59] Song, S., Lopez-Valdivieso, A., Hernandez-Campos, D. J., Peng, C., MonroyFernandez, M. G., Razo-Soto, I. Arsenic removal from high-arsenic water by enhanced coagulation with ferric ions and coarse calcite. Water Res. 2006, 40, 364-372. https://doi.org/10.1016/j.watres.2005.09.046

[60] Balasubramanian, N., and Madhavan, K. Arsenic removal from industrial effluent through electrocoagulation. Chem. Eng. Technol. 2001, 24, 519-521. https://doi.org/10.1002/1521-4125(200105)24:5<519::AID-CEAT519>3.0.CO;2-P

[61] Vasudevan, S., Lakshmi, J., Sozhan, G. Studies on the removal of arsenate by electrochemical coagulation using aluminum alloy anode. CLEAN-Soil, Air, Water. 2010, 38, 506-515. https://doi.org/10.1002/clen.201000001 
[62] Ndiaye, P. I., Moulin, P., Dominguez, L., Millet, J. C., Charbit, F. Removal of fluoride from electronic industrial effluent by RO membrane separation. Desalination, 2005, 173, 25-32. https://doi.org/10.1016/j.desal.2004.07.042

[63] Liu, X., Hu, Z., Zhu, C., Wen, G., Meng, X. Removal of fluoride and total dissolved solids from coalbed methane produced water with a movable ultra-low-pressure reverse osmosis system. Desalination Water Treat. 2013, 51, 4359-4367. https://doi.org/10.1080/19443994.2012.742853

[64] Akin, I., Arslan, G., Tor, A., Cengeloglu, Y., Ersoz, M. Removal of arsenate [As (V) and arsenite [As (III) from water by SWHR and BW-30 reverse osmosis. Desalination. 2011, 281, 88-92. https://doi.org/10.1016/j.desal.2011.07.062

[65] Hu, K., and Dickson, J. M. Nanofiltration membrane performance on fluoride removal from water. J. Membrane Sci. 2006, 279, 529-538. https://doi.org/10.1016/j.memsci.2005.12.047

[66] Chakrabortty, S., Roy, M., Pal, P. Removal of fluoride from contaminated groundwater by cross flow nanofiltration: transport modeling and economic evaluation. Desalination. 2013, 313, 115-124. https://doi.org/10.1016/j.desal.2012.12.021

[67] Nguyen, C. M., Bang, S., Cho, J., Kim, K. W. Performance and mechanism of arsenic removal from water by a nanofiltration membrane. Desalination. 2009, 245, 82-94. 10.1016/j.desal.2008.04.047

[68] Harisha, R. S., Hosamani, K. M., Keri, R. S., Nataraj, S. K., Aminabhavi, T. M. Arsenic removal from drinking water using thin film composite nanofiltration membrane. Desalination. 2010, 252, 75-80. 10.1016/j.desal.2009.10.022

[69] Kabay, N., Arar, Ö., Samatỳa, S., Yüksel, Ü., Yüksel, M. Separation of fluoride from aqueous solution by electrodialysis: Effect of process parameters and other ionic species. J. Hazard. Mater. 2008, 153, 107-113. https://doi.org/10.1016/j.jhazmat.2007.08.024

[70] Ergun, E., Tor, A., Cengeloglu, Y., Kocak, I. Electrodialytic removal of fluoride from water: Effects of process parameters and accompanying anions. Sep. Purif. Technol. 2008, 64, 147-153. https://doi.org/10.1016/j.seppur.2008.09.009

[71] Belkada, F.D., Kitous, O., Drouiche, N., Aoudj, S., Bouchelaghem, O., Abdi, N., Grib, H. Mameri, N. Electrodialysis for fluoride and nitrate removal from synthesized photovoltaic industry wastewater. Sep. Purif. Technol. 2018, 204, 108-115. https://doi.org/10.1016/j.seppur.2018.04.068

[72] Fidaleo, M., Stazi, S. R., Vinciguerra, V., Cellucci, P., Marabottini, R., Moresi, M. Assessment of the energy needs for the arsenic remediation of drinking water by electrodialysis. Desalination Water Treat. 2016, 57, 19475-19487. https://doi.org/10.1080/19443994.2015.1100557

[73] Onorato, C., Banasiak, L. J., Schäfer, A. I. Inorganic trace contaminant removal from real brackish groundwater using electrodialysis. Sep. Purif. Technol. 2017, 187, 426-435. https://doi.org/10.1016/j.seppur.2017.06.016

[74] Cooney, D. O. Adsorption design for wastewater treatment. CRC press. 1998. 
[75] Fan, X., Parker, D. J., Smith, M. D. Adsorption kinetics of fluoride on low cost materials. Water Res. 2003, 37, 4929-4937. https://doi.org/10.1016/j.watres.2003.08.014

[76] Jin, Z., Jia, Y., Zhang, K.S., Kong, L.T., Sun, B., Shen, W., Meng, F.L., Liu, J.H. Effective removal of fluoride by porous $\mathrm{MgO}$ nanoplates and its adsorption mechanism. $J$. Alloys Compd. 2016, 675, 292-300. https://doi.org/10.1016/j.jallcom.2016.03.118

[77] Yu, Z., Xu, C., Yuan, K., Gan, X., Feng, C., Wang, X., Zhu, L., Zhang, G., Xu, D. Characterization and adsorption mechanism of $\mathrm{ZrO} 2$ mesoporous fibers for healthhazardous fluoride removal. J. Hazard. Mater. 2018, 346, 82-92. https://doi.org/10.1016/j.jhazmat.2017.12.024

[78] Yadav, A. K., Abbassi, R., Gupta, A., Dadashzadeh, M. Removal of fluoride from aqueous solution and groundwater by wheat straw, sawdust and activated bagasse carbon of sugarcane. Ecol. Eng. 2013, 52, 211-218. https://doi.org/10.1016/j.ecoleng.2012.12.069

[79] Getachew, T., Hussen, A., Rao, V. M. Defluoridation of water by activated carbon prepared from banana (Musa paradisiaca) peel and coffee (Coffea arabica) husk. Int. J Environ. Sci. Technol., 2015, 12, 1857-1866. 10.1007/s13762-014-0545-8

[80] Mohan, D., Sharma, R., Singh, V. K., Steele, P., Pittman Jr, C. U. Fluoride removal from water using bio-char, a green waste, low-cost adsorbent: equilibrium uptake and sorption dynamics modeling. Ind. Eng. Chem. Res. 2012, 51, 900-914. https://doi.org/10.1021/ie202189v

[81] Amalraj, A., and Pius, A. Removal of fluoride from drinking water using aluminum hydroxide coated activated carbon prepared from bark of Morinda tinctoria. Appl. Water Sci. 2017, 7, 2653-2665. https://doi.org/10.1007/s13201-016-0479-z

[82] Nigri, E. M., Bhatnagar, A.. Rocha, S. D. F. Thermal regeneration process of bone char used in the fluoride remoyal from aqueous solution. J. Clean. Prod. 2017, 142, 35583570. https://doi.org/10.1016/j.jclepro.2016.10.112

[83] Medellín-Castillo, N.A., Cruz-Briano, S.A., Leyva-Ramos, R., Moreno-Piraján, J.C., Torres-Dosal, A., Giraldo-Gutiérrez, L., Labrada-Delgado, G.J., Pérez, R.O., RodriguezEstupiñan, J.P., Lopez, S.Y.R., Mendoza, M.S.B. Use of bone char prepared from an invasive species, pleco fish (Pterygoplichthys spp.), to remove fluoride and Cadmium (II) in water. J. Environ. Manage. 2020, 256, 109956. https://doi.org/10.1016/j.jenvman.2019.109956

[84] Raychoudhury, T., Boindala, S. P., Kalidindi, S. Performance evaluation of metal impregnated activated carbon composite for removal of fluoride under varying solution chemistry. Water Sci Tech-w Sup. 2017, 17, 1377-1385. https://doi.org/10.2166/ws.2017.040

[85] Roy, S., Das, P., Sengupta, S. Treatability study using novel activated carbon prepared from rice husk: Column study, optimization using response surface methodology and mathematical modeling. Process Saf. Environ. 2017, 105, 184-193. https://doi.org/10.1016/j.psep.2016.11.007 
[86] Singh, K., Lataye, D. H., Wasewar, K. L. Removal of fluoride from aqueous solution by using bael (Aegle marmelos) shell activated carbon: kinetic, equilibrium and thermodynamic study. J. Fluor. Chem., 2017, 194, 23-32. https://doi.org/10.1016/j.jfluchem.2016.12.009

[87] Dehghani, M. H., Farhang, M., Alimohammadi, M., Afsharnia, M., Mckay, G. Adsorptive removal of fluoride from water by activated carbon derived from $\mathrm{CaCl} 2-$ modified Crocus sativus leaves: Equilibrium adsorption isotherms, optimization, and influence of anions. Chem. Eng. Commun. 2018, 205, 955-965. https://doi.org/10.1080/00986445.2018.1423969

[88] Mullick, A., and Neogi, S. Ultrasound assisted synthesis of Mg-Mn-Zr impregnated activated carbon for effective fluoride adsorption from water. Ultrason. Sonochem. 2019, 50, 126-137. https://doi.org/10.1016/j.ultsonch.2018.09.010

[89] Inaniyan, M., and Raychoudhury, T. Application of activated carbon-metal composite for fluoride removal from contaminated groundwater in India. Int. J. Environ. Sci. Technol. 2019, 16, 7545-7554. https://doi.org/10.1007/s13762-018-2097-9

[90] Yazdani, M. R., Tuutijärvi, T., Bhatnagar, A., Vahala, R. Adsorptive removal of arsenic (V) from aqueous phase by feldspars: Kinetics, mechanism, and thermodynamic aspects of adsorption. J. Mol. Liq 2016, 214, 149-156. https://doi.org/10.1016/j.molliq.2015.12.002

[91] Sahu, U. K., Sahu, S., Mahapatra, S. S., Patel, R. K. Cigarette soot activated carbon modified with $\mathrm{Fe} 3 \mathrm{O} 4$ nanoparticles as an effective adsorbent for As (III) and As (V): material preparation, characterization and adsorption mechanism study. J. Mol. Liq. 2017, 243, 395-405. https://doi.org/10.1016/3.molliq.2017.08.055

[92] Zhang, M., Gao, B., Varnoosfaderani, S., Hebard, A., Yao, Y., Inyang, M. Preparation and characterization of a nove Rmagnetic biochar for arsenic removal. Bioresour. Technol. 2013, 130, 457-462. https/doi.org/10.1016/j.biortech.2012.11.132

[93] Asadullah, M., Jahan, I., Ahmed, M. B., Adawiyah, P., Malek, N. H., Rahman, M. S. Preparation of microporous activated carbon and its modification for arsenic removal from water. J. Ind. Eng. Chem. 2014, 20, 887-896. https://doi.org/10.1016/j.jiec.2013.06.019

[94] Vieira, B. R., Pintor, A. M., Boaventura, R. A., Botelho, C. M., Santos, S. C. Arsenic removal from water using iron-coated seaweeds. J. Environ. Manage. 2017, 192, 224-233. https://doi.org/10.1016/j.jenvman.2017.01.054

[95] Xiong, Y., Tong, Q., Shan, W., Xing, Z., Wang, Y., Wen, S., Lou, Z. Arsenic transformation and adsorption by iron hydroxide/manganese dioxide doped straw activated carbon. Appl. Surf. Sci. 2017, 416, 618-627. https://doi.org/10.1016/j.apsusc.2017.04.145

[96] Niazi, N.K., Bibi, I., Shahid, M., Ok, Y.S., Burton, E.D., Wang, H., Shaheen, S.M., Rinklebe, J., Lüttge, A. Arsenic removal by perilla leaf biochar in aqueous solutions and groundwater: an integrated spectroscopic and microscopic examination. Environ. Pollut., 2018, 232, 31-41. https://doi.org/10.1016/j.envpol.2017.09.051

[97] Niazi, N.K., Bibi, I., Shahid, M., Ok, Y.S., Shaheen, S.M., Rinklebe, J., Wang, H., Murtaza, B., Islam, E., Nawaz, M.F., Lüttge, A. Arsenic removal by Japanese oak wood 
biochar in aqueous solutions and well water: Investigating arsenic fate using integrated spectroscopic and microscopic techniques. Sci. Total Environ. 2018, 621, 1642-1651. https://doi.org/10.1016/j.scitotenv.2017.10.063

[98] Yu, Y., Zhang, C., Yang, L., Chen, J. P. Cerium oxide modified activated carbon as an efficient and effective adsorbent for rapid uptake of arsenate and arsenite: Material development and study of performance and mechanisms. Chem. Eng. J. 2017, 315, 630638. https://doi.org/10.1016/j.cej.2016.09.068

[99] Sahu, U. K., Mahapatra, S. S., Patel, R. K. Application of Box-Behnken Design in response surface methodology for adsorptive removal of arsenic from aqueous solution using $\mathrm{CeO} 2 / \mathrm{Fe} 2 \mathrm{O} 3 /$ graphene nanocomposite. Mater. Chem. Phys. 2018, 207, 233-242. https://doi.org/10.1016/j.matchemphys.2017.11.042

[100] Guo, F., Jiang, X., Li, X., Jia, X., Liang, S., Qian, L. Synthesis of MgO/Fe3O4 nanoparticles embedded activated carbon from biomass for high-efficient adsorption of malachite green. Mater. Chem. Phys. 2020, 240, 122240. https://doi.org/10.1016/j.matchemphys.2019.122240

[101] Zhou, Z., Liu, Y.G., Liu, S.B., Liu, H.Y., Zeng, G.M», Tan, X.F., Yang, C.P., Ding, Y., Yan, Z.L., Cai, X.X. Sorption performance and mechanisms of arsenic (V) removal by magnetic gelatin-modified biochar. Chem. Eng. J. 2017, 314, 223-231. https://doi.org/10.1016/j.cej.2016.12.113

[102] Adlnasab, L., Shekari, N., Maghsodi, A. Optimization of arsenic removal with Fe3O4@A12O3@Zn-Fe LDH as a new magnetic nano adsorbent using Box-Behnken design. J. Environ. Chem. Eng. 2019, 7, 102974. https://doi.org/10.1016/j.jece.2019.102974

[103] Rahman, H. L., Erdem, H., Sahin, M., Erdem, M. Iron-Incorporated Activated Carbon Synthesis from Biomass Mixture for Enhanced Arsenic Adsorption. Water Air Soil Pollut., 2020, 231, 6. https:/doi.org/10.1007/s11270-019-4378-4

[104] Zhu, N., Qiao, J., Ye, Y., Yan, T. Synthesis of mesoporous bismuth-impregnated aluminum oxide for arsenic removal: adsorption mechanism study and application to a labscale column. J. Environ. Manage. 2018, 211, 73-82. https://doi.org/10.1016/j.jenvman.2018.01.049

[105] Kumar, R., Kang, C. U., Mohan, D., Khan, M. A., Lee, J. H., Lee, S. S., Jeon, B. H. Waste sludge derived adsorbents for arsenate removal from water. Chemosphere. 2020, 239, 124832. https://doi.org/10.1016/j.chemosphere.2019.124832

[106] Leus, K., Folens, K., Nicomel, N.R., Perez, J.P.H., Filippousi, M., Meledina, M., Dîrtu, M.M., Turner, S., Van Tendeloo, G., Garcia, Y., Du Laing, G. Removal of arsenic and mercury species from water by covalent triazine framework encapsulated $\gamma$-Fe2O3 nanoparticles. J. Hazard. Mater. 2018, 353, 312-319. https://doi.org/10.1016/j.jhazmat.2018.04.027

[107] Taleb, K., Markovski, J., Veličković, Z., Rusmirović, J., Rančić, M., Pavlović, V., Marinković, A. Arsenic removal by magnetite-loaded amino modified nano/microcellulose 
adsorbents: Effect of functionalization and media size. Arab. J. Chem. 2019, 12, 46754693. https://doi.org/10.1016/j.arabjc.2016.08.006

[108] Karmakar, S., Dechnik, J., Janiak, C., De, S. Aluminium fumarate metal-organic framework: A super adsorbent for fluoride from water. J. Hazard. Mater. 2016, 303, 10 20. https://doi.org/10.1016/j.jhazmat.2015.10.030

[109] Wang, C., Liu, X., Chen, J. P., Li, K. Superior removal of arsenic from water with zirconium metal-organic framework UiO-66. Sci. Rep. 2015, 5, 16613. https://doi.org/10.1038/srep16613

[110] Li, J. R., Sculley, J., Zhou, H. C. Metal-organic frameworks for separations. Chem. Rev. 2012, 112, 869-932. https://doi.org/10.1021/cr200190s

[111] Borboudakis, G., Stergiannakos, T., Frysali, M., Klontzas, E., Tsamardinos, I., Froudakis, G. E. Chemically intuited, large-scale screening of MOFs by machine learning techniques. Npj Comput. Mater. 2017, 3, 1-7. https://doi.org/10.1038/s41524-017-0045-8

[112] Perez, E. V., Karunaweera, C., Musselman, I. H., Balkus, K. J., Ferraris, J. P. Origins and evolution of inorganic-based and MOF-based mixed-matrix membranes for gas separations. Processes. 2017, 4, 32. https://doi.org/10.3390/pr4030032

[113] Furukawa, H., Cordova, K. E., O'Keeffe, M. Yaghi, O. M. The chemistry and applications of metal-organic frameworks. Science, 2013, 341, 1230444. https://doi.org/10.1126/science. 1230444

[114] Tranchemontagne, D. J., Mendoza-Cortés, J. L., O’Keeffe, M., Yaghi, O. M. Secondary building units, nets and bonding in the chemistry of metal-organic frameworks. Chem. Soc. Rev. 2009, 38, 1257-1283. https://doi.org/10.1039/B817735J

[115] Dai, J., Xiao, X., Duan, S., Liu, J., He, J., Lei, J., Wang, L. Synthesis of novel microporous nanocomposites of ZIF-8 on multiwalled carbon nanotubes for adsorptive removing benzoic acid from water. Chem. Eng. J. 2018, 331, 64-74. https://doi.org/10.1016/j.cej.2017.08.090

[116] Solis, K. L. B., Kwon, Y. H., Kim, M. H., An, H. R., Jeon, C., Hong, Y. Metal organic framework UiO-66 and activated carbon composite sorbent for the concurrent adsorption of cationic and anionic metals. Chemosphere. 2020, 238, 124656. https://doi.org/10.1016/j.chemosphere.2019.124656

[117] Tranchemontagne, D. J., Hunt, J. R., Yaghi, O. M. Room temperature synthesis of metal-organic frameworks: MOF-5, MOF-74, MOF-177, MOF-199, and IRMOF-0. Tetrahedron. 2008, 64, 8553-8557. https://doi.org/10.1016/j.tet.2008.06.036

[118] Dang, Y.T., Hoang, H.T., Dong, H.C., Bui, K.B.T., Nguyen, L.H.T., Phan, T.B., Kawazoe, Y., Doan, T.L.H. Microwave-assisted synthesis of nano Hf-and Zr based metalorganic frameworks for enhancement of curcumin adsorption. Micropor. Mesopor. Mat. 2020, 298, 110064. https://doi.org/10.1016/j.micromeso.2020.110064

[119] Klimakow, M., Klobes, P., Thünemann, A. F., Rademann, K., Emmerling, F. Mechanochemical synthesis of metal- organic frameworks: a fast and facile approach 
toward quantitative yields and high specific surface areas. Chem. Mater. 2010, 22, 52165221. https://doi.org/10.1021/cm1012119

[120] Tanhaei, M., Mahjoub, A. R., Safarifard, V. Sonochemical synthesis of amidefunctionalized metal-organic framework/graphene oxide nanocomposite for the adsorption of methylene blue from aqueous solution. Ultrason. Sonochem., 2018, 41, 189-195. https://doi.org/10.1016/j.ultsonch.2017.09.030

[121] Martinez Joaristi, A., Juan-Alcañiz, J., Serra-Crespo, P., Kapteijn, F., Gascon, J. Electrochemical synthesis of some archetypical $\mathrm{Zn} 2+, \mathrm{Cu} 2+$, and $\mathrm{Al} 3+$ metal organic frameworks. Cryst. Growth Des. 2012, 12, 3489-3498. https://doi.org/10.1021/cg300552w

[122] Stock, N., and Biswas, S. Synthesis of metal-organic frameworks (MOFs): routes to various MOF topologies, morphologies, and composites. Chem. Rev. 2012, 112, 933-969. https://doi.org/10.1021/cr200304e

[123] Liu, J., Chen, L., Cui, H., Zhang, J., Zhang, L., Su, C. Y. Applications of metalorganic frameworks in heterogeneous supramolecular catalysis. Chem. Soc. Rev. 2014, 43, 6011-6061. https://doi.org/10.1039/C4CS00094C

[124] Abbasi, A., Moradpour, T., Van Hecke, K. A new 3D cobalt (II) metal-organic framework nanostructure for heavy metal adsorption. Inorganica Chim. Acta. 2015, 430, 261-267. https://doi.org/10.1016/j.ica.2015.03.019

[125] Yu, C., Shao, Z., Hou, H. A functionalized metal-organic framework decorated with O- groups showing excellent performance for lead (II) removal from aqueous solution. Chem. Sci. 2017, 8, 7611-7619. 10.1039/G7SC03308G

[126] Dhaka, S., Kumar, R., Deep, A., Kurade, M. B., Ji, S. W., Jeon, B. H. Metal-organic frameworks (MOFs) for the removal of emerging contaminants from aquatic environments. Coord. Chem. Rev. 2019, 380, 330-352. https://doi.org/10.1016/j.cer.2018.10.003

[127] Zhao, X., Liu, D., Huang, H., Zhang, W., Yang, Q., Zhong, C. The stability and defluoridation performance of MOFs in fluoride solutions. Micropor. Mesopor. Mat. 2014, 185, 72-78. https://doi.org/10.1016/j.micromeso.2013.11.002

[128] Ma, A., Ke, F., Jiang, J., Yuan, Q., Luo, Z., Liu, J., Kumar, A. Two lanthanide-based metal-organic frameworks for highly efficient adsorption and removal of fluoride ions from water. Cryst. Eng. Comm. 2017, 19, 2172-2177. https://doi.org/10.1039/C7CE00291B

[129] He, J., Cai, X., Chen, K., Li, Y., Zhang, K., Jin, Z., Meng, F., Liu, N., Wang, X., Kong, L., Huang, X. Performance of a novelly-defined zirconium metal-organic frameworks adsorption membrane in fluoride removal. J. Colloid Interface Sci. 2016, 484, 162-172. 10.1016/j.jcis.2016.08.074.

[130] Lin, K. Y. A., Liu, Y. T., Chen, S. Y. Adsorption of fluoride to UiO-66-NH2 in water: stability, kinetic, isotherm and thermodynamic studies. J. Colloid Interface Sci. 2016, 461, 79-87. https://doi.org/10.1016/j.jcis.2015.08.061 
[131] Zhu, X. H., Yang, C. X., Yan, X. P. Metal-organic framework-801 for efficient removal of fluoride from water. Micropor. Mesopor. Mat. 2018, 259, 163-170. https://doi.org/10.1016/j.micromeso.2017.10.001

[132] Ke, F., Peng, C., Zhang, T., Zhang, M., Zhou, C., Cai, H., Zhu, J., Wan, X. Fumaratebased metal-organic frameworks as a new platform for highly selective removal of fluoride from brick tea. Sci. Rep. 2018, 8, 1-11. https://doi.org/10.1038/s41598-018-19277-2

[133] Massoudinejad, M., Ghaderpoori, M., Shahsavani, A., Amini, M. M. Adsorption of fluoride over a metal organic framework Uio-66 functionalized with amine groups and optimization with response surface methodology. J. Mol. Liq., 2016, 221, 279-286. https://doi.org/10.1016/j.molliq.2016.05.087

[134] Jian, M., Liu, B., Zhang, G., Liu, R., and Zhang, X. Adsorptive removal of arsenic from aqueous solution by zeolitic imidazolate framework-8 (ZIF-8) nanoparticles. Colloids Surf. A Physicochem. Eng. Asp. 2015, 465, 67-76. https://doi.org/10.1016/j.colsurfa.2014.10.023

[135] Tarboush, B. A., Chouman, A., Jonderian, A., Ahmad, M., Hmadeh, M., Al-Ghoul, M. Metal-Organic Framework-74 for Ultratrace Arsenic Removal from Water: Experimental and Density Functional Theory Studies. ACS Appl. Nano Mater. 2018, 1, 3283-3292. https://doi.org/10.1021/acsanm.8b00501

[136] Atallah, H., Mahmoud, M. E., Jelle, A., Lough, A., Hmadeh, M. A highly stable indium-based metal organic framework for efficient arsenic removal from water. Dalton Trans. 2018, 47, 799-806. https://doi.org/10.1039/C7DT03705H

[137] Xie, D., Ma, Y., Gu, Y., Zhou, H., Zhang, H., Wang, G., Zhang, Y. Zhao, H. Bifunctional NH2-MIL-88 (Fe) metal-organic framework nanooctahedra for highly sensitive detection and efficient removal of arsenate in aqueous media. J. Mater. Chem. A. 2017, 5, 23794-23804. https://doi.org/10.1039/C7TA07934F

[138] Vu, T.A., Le, G.H., Dao, C.D., Dang, L.Q., Nguyen, K.T., Nguyen, Q.K., Dang, P.T., Tran, H.T., Duong, Q.T., Nguyen, T.V., Lee, G.D. Arsenic removal from aqueous solutions by adsorption using novel MIL-53 (Fe) as a highly efficient adsorbent. Rsc Adv. 2015, 5, 5261-5268. https://doi.org/10.1039/C4RA12326C

[139] Sarker, M., Song, J. Y., Jhung, S. H. Adsorption of organic arsenic acids from water over functionalized metal-organic frameworks. J. Hazard. Mater. 2017, 335, 162-169. https://doi.org/10.1016/j.jhazmat.2017.04.044

[140] Li, Z. Q., Yang, J. C., Sui, K. W., Yin, N. Facile synthesis of metal-organic framework MOF-808 for arsenic removal. Materials Letters. 2015, 160, 412-414.

[141] Li, J., Wu, Y. N., Li, Z., Zhu, M., Li, F. Characteristics of arsenate removal from water by metal-organic frameworks (MOFs). Water Sci. Technol. 2014, 70, 1391-1397. $\underline{10.2166 / \text { wst.2014.390. }}$

[142] Li, J., Wu, Y.N., Li, Z., Zhang, B., Zhu, M., Hu, X., Zhang, Y., Li, F. Zeolitic imidazolate framework- 8 with high efficiency in trace arsenate adsorption and removal from water. J. Phys. Chem. C. 2014, 118, 27382-27387. https://doi.org/10.1021/jp508381m 
[143] He, Y., Tang, Y. P., Ma, D., Chung, T. S. UiO-66 incorporated thin-film nanocomposite membranes for efficient selenium and arsenic removal. J. Membrane. Sci. 2017, 541, 262-270. https://doi.org/10.1016/j.memsci.2017.06.061

[144] Folens, K., Leus, K., Nicomel, N.R., Meledina, M., Turner, S., Van Tendeloo, G., Laing, G.D., Van Der Voort, P. Fe3O4@ MIL-101-A Selective and Regenerable Adsorbent for the Removal of As Species from Water. Eur. J. Inorg. Chem., 2016, 2016, 4395-4401. https://doi.org/10.1002/ejic.201600160

[145] Wu, Y.N., Zhou, M., Zhang, B., Wu, B., Li, J., Qiao, J., Guan, X., Li, F. Amino acid assisted templating synthesis of hierarchical zeolitic imidazolate framework- 8 for efficient arsenate removal. Nanoscale, 2014, 6, 1105-1112. https://doi.org/10.1039/C3NR04390H

[146] Pang, D., Wang, P., Fu, H., Zhao, C., Wang, C. C. Highly efficient removal of As (V) using metal-organic framework BUC-17. SN Applied Sciences. 2020, 2, 184. $\underline{10.1007 / \mathrm{s} 42452-020-1981-3}$

[147] Chen, S., Yue, Q., Gao, B., Li, Q., Xu, X., Fu, K. Adsorption of hexavalent chromium from aqueous solution by modified corn stalk: a fixed-bed column study. Bioresour. Technol. 2012, 113, 114-120. https://doi.org/10.1016/j.biortech.2011.11.110

[148] Thomas, H. C. Heterogeneous ion exchange in a flowing system. J. Am. Chem. Soc., 1994, 66, 1664-1666. https://doi.org/10.1021/ja01238a017

[149] Han, R., Ding, D., Xu, Y., Zou, W., Wang, Y., Li, Y., Zou, L. Use of rice husk for the adsorption of congo red from aqueous solution in column mode. Bioresour. Technol. 2008, 99, 2938-2946. https://doi,org/10.1016/j.biortech.2007.06.027 


\section{$\underline{\text { List of Figures }}$}

Fig. 1. Basic structure of MOF's (Secondary building units (SBUs) (metal node) and organic linkers used for the synthesis of IRMOF-1 and HKUST-1) [111]

Fig. 2. Different metal organic frameworks (MOFs) obtained using the same SBU with different organic linkers [112]

Fig. 3a. Inorganic secondary building units [113]

Fig. 3b. Organic linkers commonly used in MOF synthesis [113]

Fig. 4. Different synthesis methods

Fig. 5. Different synthesis methods with possible reaction temperatures, and final reaction products in MOF synthesis [122]

Fig. 6. Classification of MOFs [123]

Fig. 7. Possible uptake mechanisms for adsorptive removal [126]

\section{List of Tables}

Table 1. Different methods for fluoride and arsenic uptake

Table 2. Different adsorbents for fluoride and arsenic uptake

Table 3. Different mechanisms for fluoride and arsenic uptake by MOFs

Table 4. Breakthrough time and cost analysis of MOFs for fluoride and arsenic uptake 


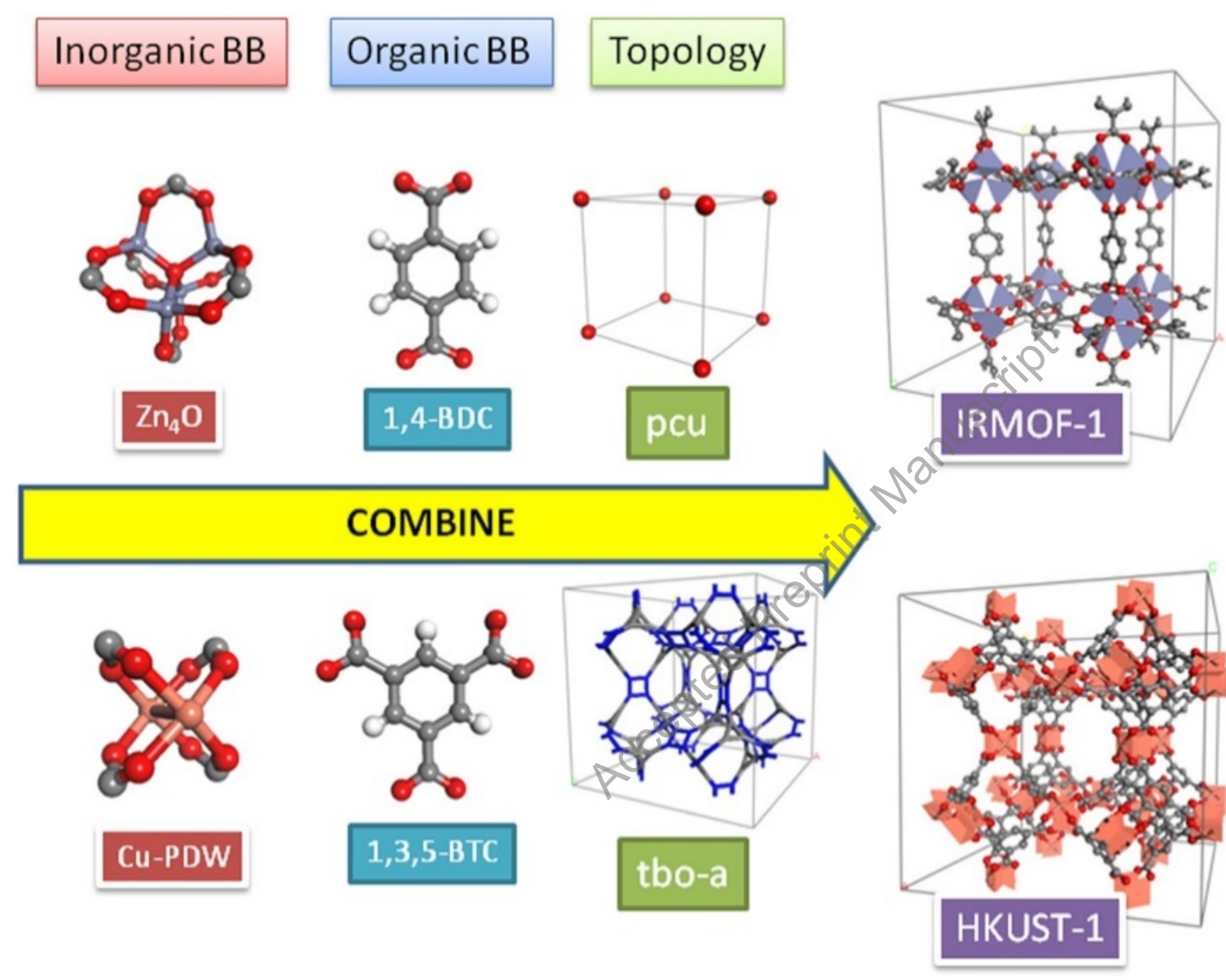

Fig. 1. Basic structure of MOF's (Secondary building units (SBUs) (metal node) and organic linkers used for the synthesis of IRMOF-1 and HKUST-1) [111] 


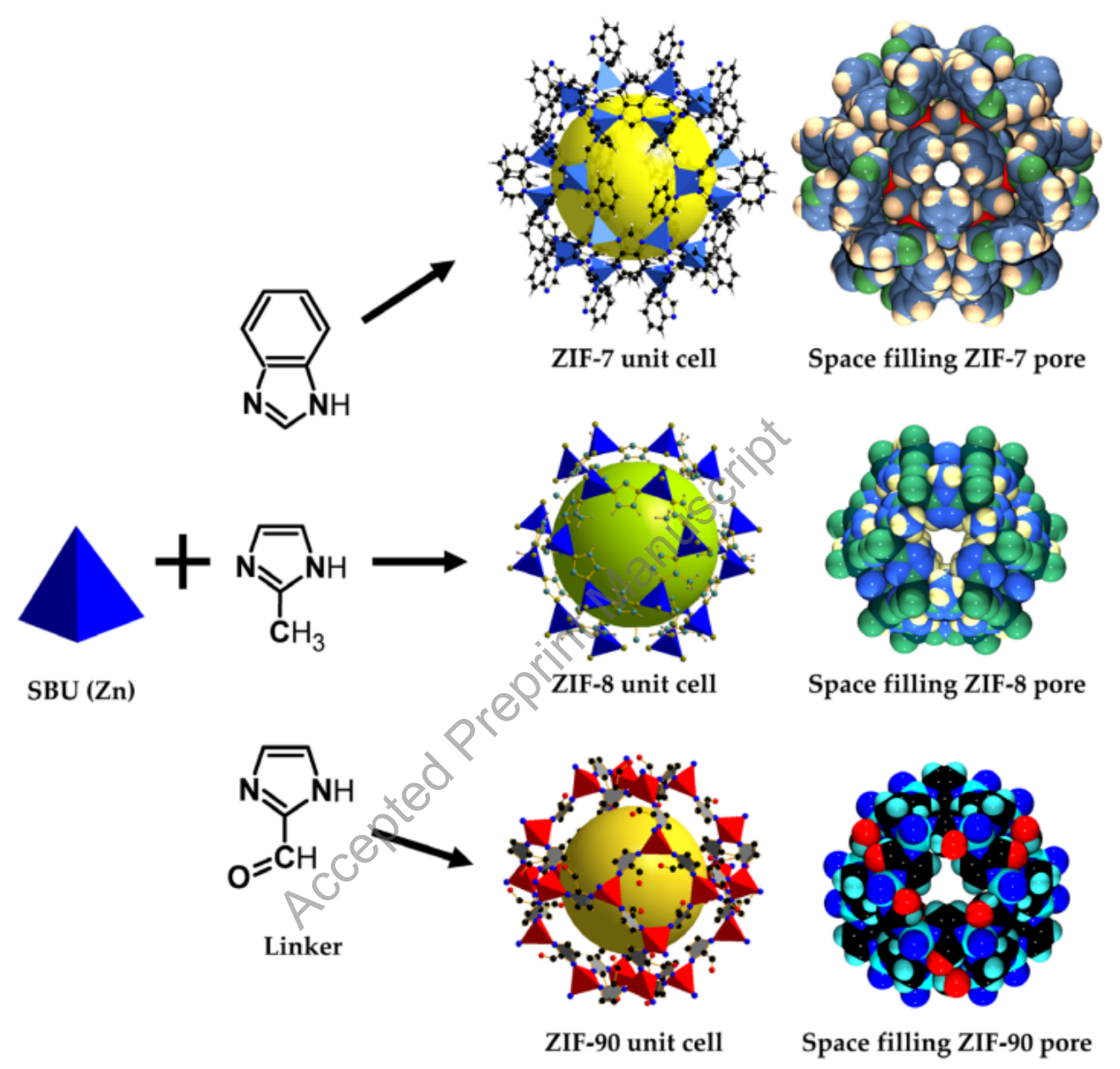

Fig. 2. Different metal organic frameworks (MOFs) obtained using the same SBU with different organic linkers [112] 


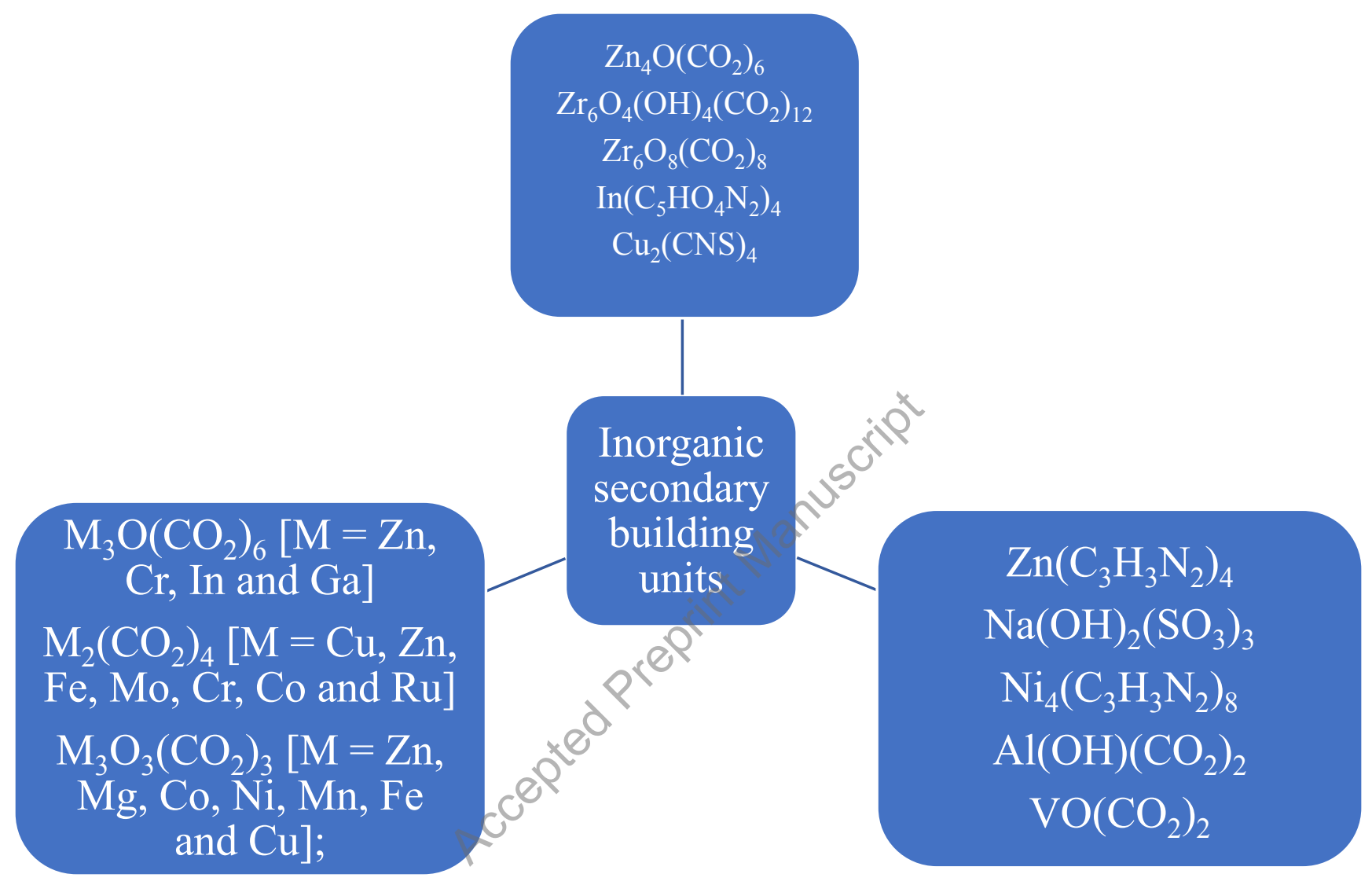

Fig. 3a. Inorganic secondary building units [113] 


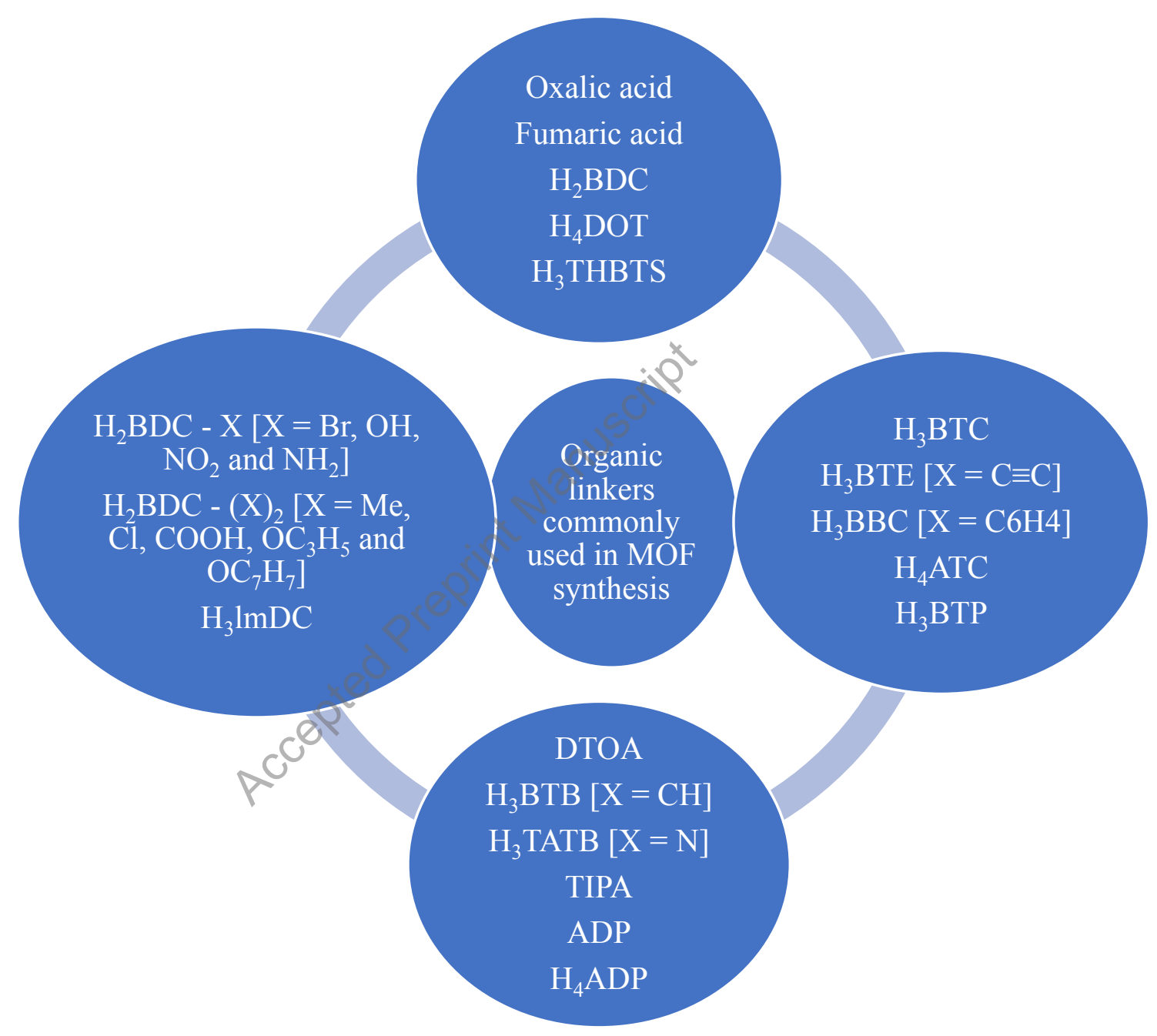

Fig. 3b. Organic linkers commonly used in MOF synthesis [113] 


\section{Synthesis methods}

Solvothermal/

Hydrothermal

\section{Microwave assisted}

Sonochemical

Electrochemical

Mechanochemical

Fig. 4. Different synthesis methods 


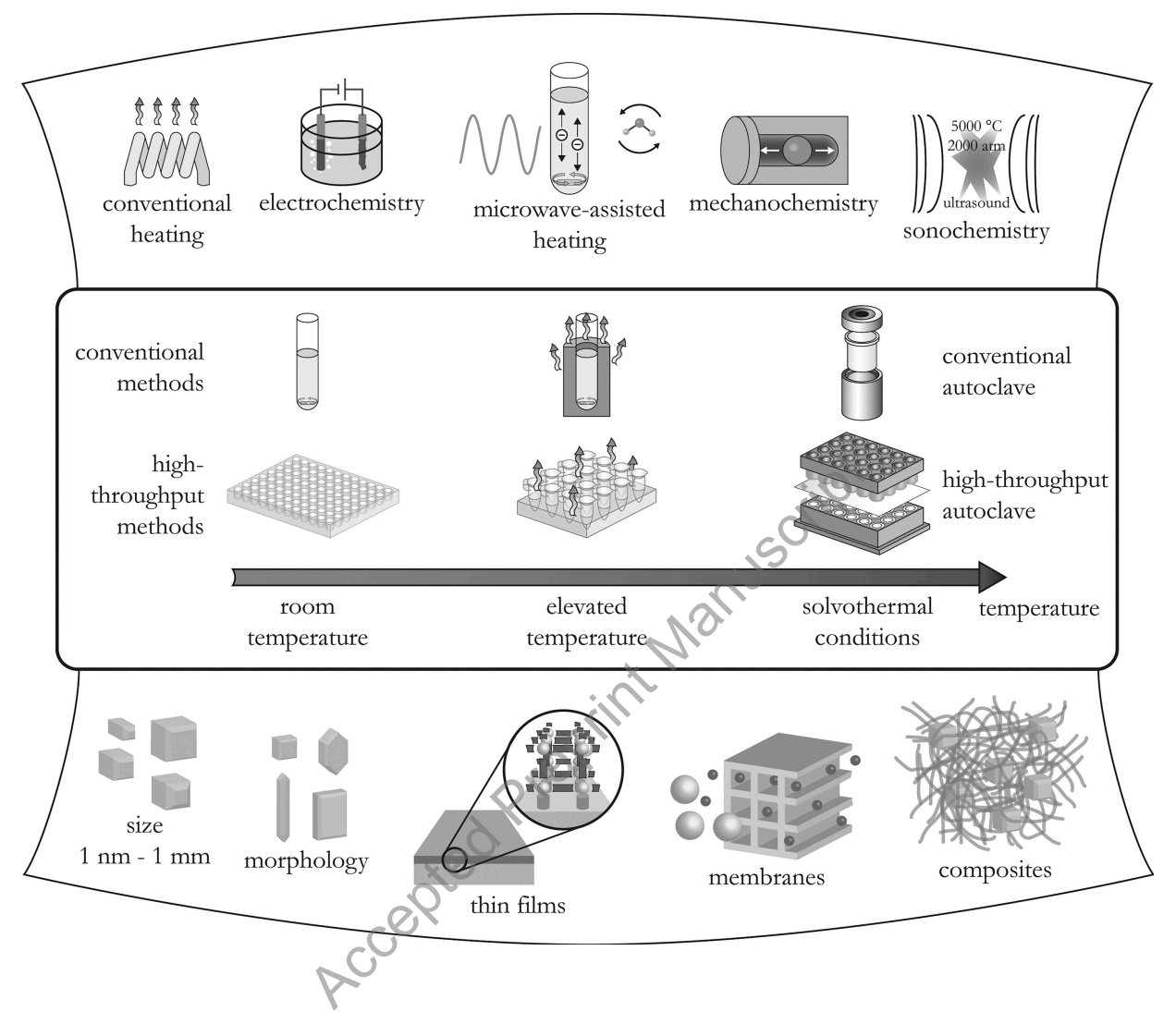

Fig. 5. Different synthesis methods with possible reaction temperatures, and final reaction products in MOF synthesis [122] 


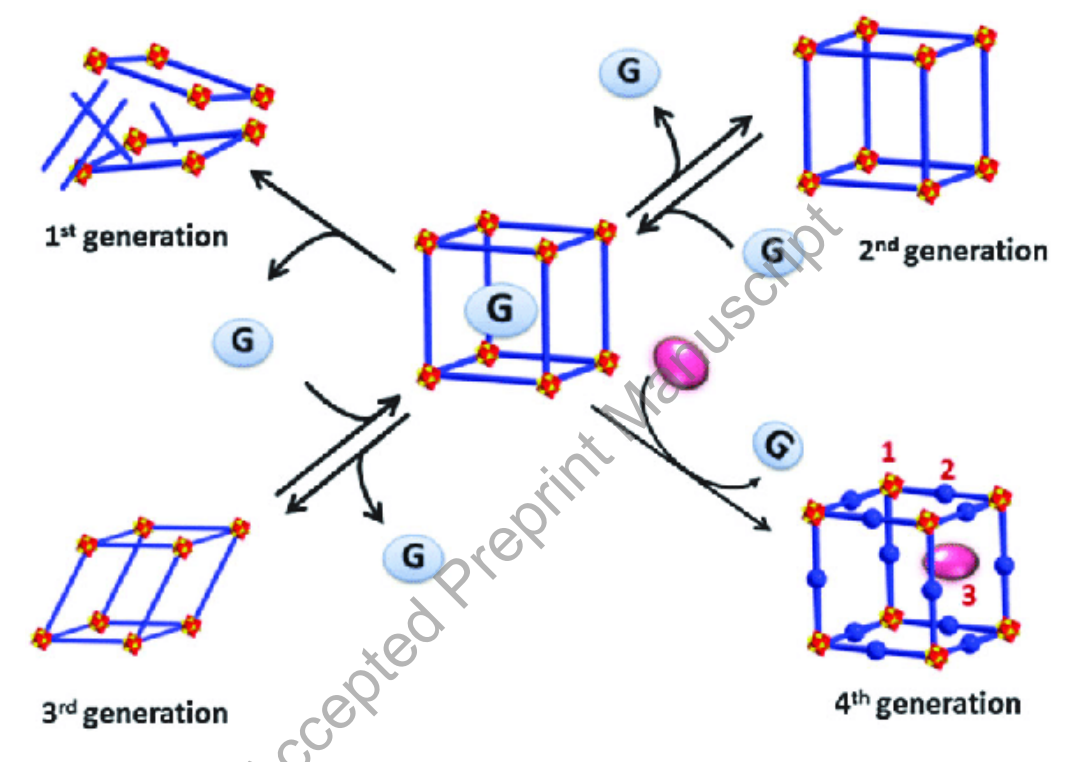

Fig. 6. Classification of MOFs [123] 


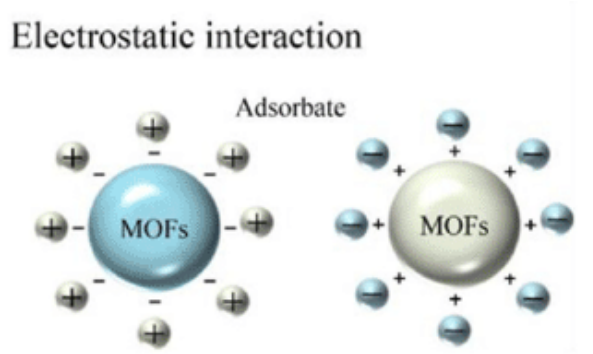

Influence of framework metal

Hydrogen bonding
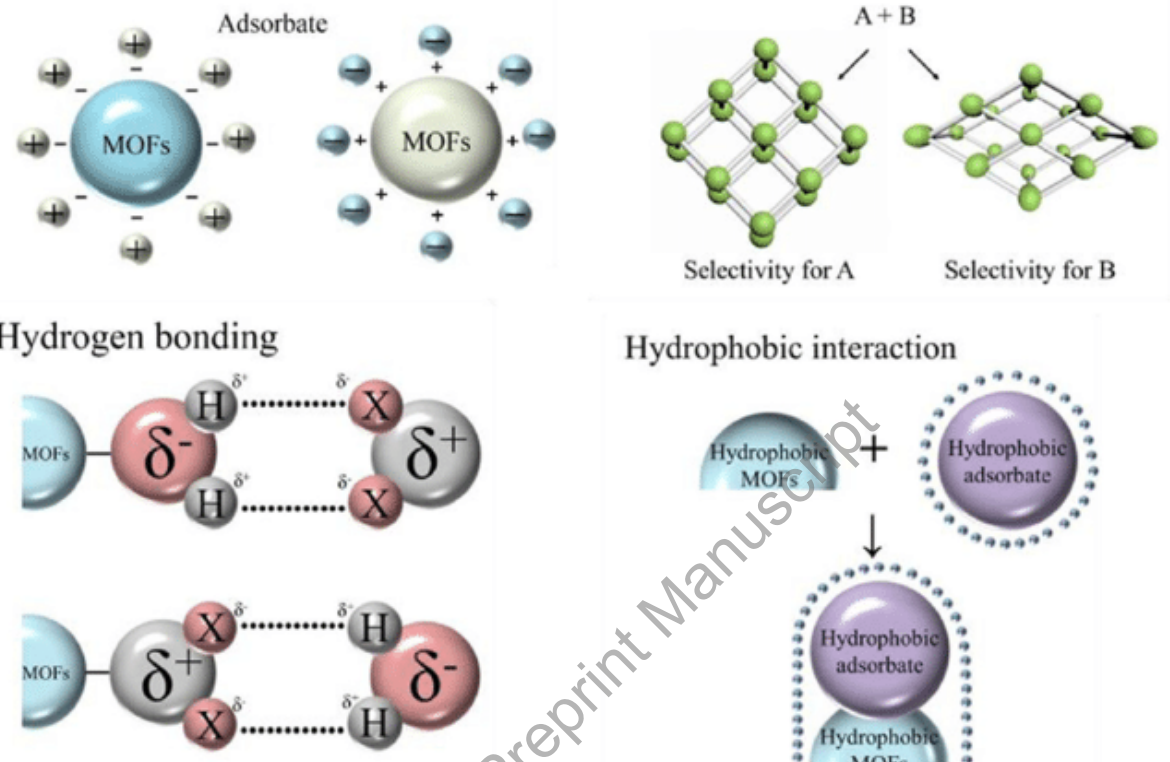

Hydrophobic interaction

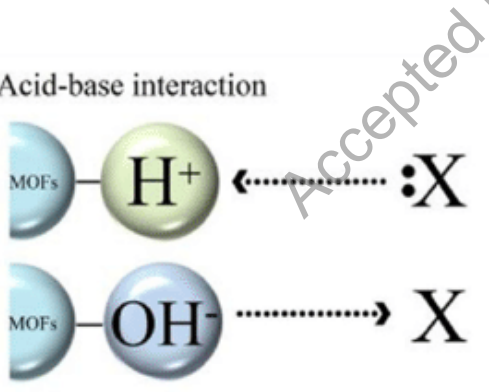

$\pi-\pi$ interaction/staking

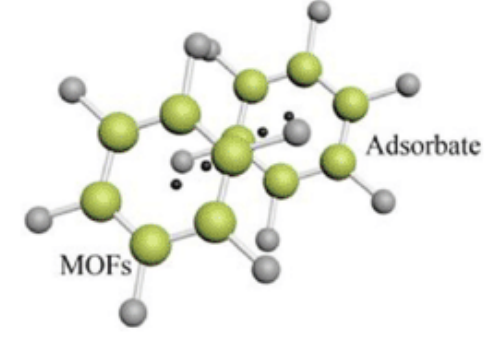

Fig. 7. Possible uptake mechanisms for adsorptive removal [126] 
Table 1. Different methods for fluoride and arsenic uptake

\begin{tabular}{|c|c|c|c|c|}
\hline S.No & Uptake method & Pollutant & Major Observations & Reference \\
\hline 1. & $\begin{array}{l}\text { Precipitation using two-column limestone } \\
\text { reactor }\end{array}$ & Fluoride & $\begin{array}{l}\text { - From the profile sampling, it was observed that fluoride } \\
\text { concentration was reduced from } 109 \mathrm{mg} / \mathrm{L} \text { to } 8 \mathrm{mg} / \mathrm{L} \\
\text { within first } 35 \text { minutes and finally decreased below the } \\
\text { MCL limit of } 4 \mathrm{mg} / \mathrm{L} \\
\text { - Advantage of minimal monitoring and no requirement } \\
\text { of column regeneration over the existing ion exchange } \\
\text { and lime process. }\end{array}$ & {$[13]$} \\
\hline 2. & Precipitation using crushed limestone & Fluoride & $\begin{array}{l}\text { - As evident from AFM and XPS analysis fluoride } \\
\text { adsorption occurred over entire calcite surface. } \\
\text { Precipitation was maximum when dissolved calcium } \\
\text { concentration was highest. }\end{array}$ & {$[53]$} \\
\hline 4. & $\begin{array}{l}\text { Arsenic co-precipitation with ferric } \\
\text { hydroxide using calcium in the presence } \\
\text { of silicate }\end{array}$ & Arsenic & $\begin{array}{l}\left.\text { - The results of photometric dispersion analysis ( } \mathrm{R}_{\mathrm{PDA}}\right) \\
\text { indicated that in presence of silicate ion, zeta potential } \\
\text { of calcium increased. } \\
\text { - Calcium ions facilitate ferric precipitation and reduce } \\
\text { filtrate ion concentration enhancing arsenic removal. }\end{array}$ & {$[54]$} \\
\hline 6. & $\begin{array}{l}\text { Arsenic removal by precipitation with } \\
\text { calcium phosphate hydroxyapatite }\end{array}$ & Arsenic & $\begin{array}{l}\text { - Results indicated that a higher molar ratio of calcium } \\
\text { gives higher arsenic removal efficiency. } \\
\text { - The pH of initial solution does not significantly affect } \\
\text { the removal. }\end{array}$ & {$[55]$} \\
\hline 7. & $\begin{array}{l}\text { Continuous flow electrocoagulation } \\
\text { reactor }\end{array}$ & Fluoride & $\begin{array}{l}\text { - The reactor with monopolar aluminium electrodes were } \\
\text { used to study the effect of various parameters, such as, }\end{array}$ & {$[56]$} \\
\hline
\end{tabular}




\begin{tabular}{|c|c|c|c|c|}
\hline & & & $\begin{array}{l}\mathrm{pH} \text {, current density, flow rate, residence time and } \\
\text { fluoride concentration on removal efficiency. } \\
\text { - XRD spectrum of the produced sludge showed } \\
\text { presence of aluminium hydroxide }\left(\mathrm{Al}(\mathrm{OH})_{3}\right) \text {, which } \\
\text { maximizes formation of aluminium fluoride-hydroxide } \\
\text { complexes }\left(\mathrm{Al}_{\mathrm{n}} \mathrm{F}_{\mathrm{m}}(\mathrm{OH})_{3 \mathrm{n}-\mathrm{m}) \text { thereby leading to }}\right. \\
\text { defluoridation }\end{array}$ & \\
\hline 8. & $\begin{array}{l}\text { Parallel-plate electrocoagulation process } \\
\text { using aluminium electrodes }\end{array}$ & Fluoride & $\begin{array}{l}\text { - Removal efficiency of fluoride was observed to be } 93 \% \\
\text { within five minutes of HRT. } \\
\text { - The optimat } \mathrm{pH} \text { range of the influent stream was } \\
\text { between } 67 \text {. At this pH range, effective defluoridation } \\
\text { was achreved with no pH re-adjustment. }\end{array}$ & [57] \\
\hline 9. & $\begin{array}{l}\text { Coagulation using Moringa oleifera seed } \\
\text { extract }\end{array}$ & Fluoride & $\begin{array}{l}\text { - Focus of this work was to optimize fluoride removal } \\
\text { using response surface methodology and the Box- } \\
\text { Benkhen model. The developed quadratic model } \\
\text { suggests that } \mathrm{pH} \text { has no significant effect in the removal } \\
\text { process. }\end{array}$ & [58] \\
\hline 12. & $\begin{array}{l}\text { Enhanced coagulation process with ferric } \\
\text { ions and coarse calcite }\end{array}$ & Arsenice & $\begin{array}{l}\text { - Coagulation was enhanced due to coating, thereby } \\
\text { improving the filtration and sedimentation } \\
\text { significantly. } \\
\text { - Improvement in coagulation was due to a phenomena } \\
\text { termed as "coarse particle" effect. This effect can be } \\
\text { attributed to increase in aggregation rate, because } \\
\text { collision rate between coarse particle and fine particle } \\
\text { is much higher than that between fine particles } \\
\text { themselves. }\end{array}$ & [59] \\
\hline
\end{tabular}




\begin{tabular}{|c|c|c|c|c|}
\hline 10. & $\begin{array}{l}\text { Electrocoagulation with mild steel and } \\
\text { stainless-steel plates as anode and } \\
\text { cathode }\end{array}$ & Arsenic & $\begin{array}{l}\text { - Batch electrochemical reactor was utilized for removal } \\
\text { studies, with a varied range of operating conditions, } \\
\text { such as, initial arsenic concentration, pH and reactor } \\
\text { volume. } \\
\text { - It was observed that there was a reduction in the } \\
\text { generation of solid sludge, while release of ferric ions } \\
\text { was easily controlled by adjusting the operating } \\
\text { conditions. }\end{array}$ & {$[60]$} \\
\hline 13. & $\begin{array}{l}\text { Electrocoagulation using aluminum alloy } \\
\text { as anode and stainless steel as the } \\
\text { cathode }\end{array}$ & $\operatorname{Arsenic}(\operatorname{As}(\mathrm{V}))$ & $\begin{array}{l}\text { - Removal efficiency of } 98.4 \% \text { was achieved, at current } \\
\text { density of } 0.2 \text { ampere/ } \mathrm{dm}^{2} \text { and } \mathrm{pH} 7 \text {. } \\
\text { - Aluminium hydroxide generated in the cell removed } \\
\text { arsenate to permissible level }(0.01 \mathrm{mg} / \mathrm{L}) \text {. } \\
\text { - The effect of coexisting ions, such as, carbonate, } \\
\text { phosphate, silicate and fluoride were studied. It was } \\
\text { observed that there was significant decrease in arsenic } \\
\text { removal efficiency in presence of these ions. } \\
\text { - Above } 5 \mathrm{mg} / \mathrm{L} \text { of carbonate concentration, removal } \\
\text { efficiency of arsenic reduces due to anode passivation. } \\
\text { - As silicate concentration increases, interaction of } \\
\text { arsenic with aluminium hydroxide was enhanced, } \\
\text { resulting in the formation of colloids that decreases } \\
\text { removal efficiency in turn. } \\
\text { - Also, with an increase in phosphate and fluoride ions, } \\
\text { arsenate removal was observed to decrease due to } \\
\text { preferential adsorption of phosphate and fluoride over } \\
\text { the latter. }\end{array}$ & {$[61]$} \\
\hline 14. & Reverse osmosis & Fluoride & $\begin{array}{l}\text { - Retention factor was over } 98 \% \text {, suggesting that RO } \\
\text { membrane could be considered for defluoridation at } \\
\text { higher feed concentrations. }\end{array}$ & {$[62]$} \\
\hline
\end{tabular}




\begin{tabular}{|c|c|c|c|c|}
\hline & & & $\begin{array}{l}\text { - However, with increase in upstream concentration, } \\
\text { downstream concentration and osmotic pressure } \\
\text { increases, thereby limiting the process }\end{array}$ & \\
\hline 15. & $\begin{array}{l}\text { Portable ultra-low pressure reverse } \\
\text { osmosis system }\end{array}$ & $\begin{array}{l}\text { Fluoride, Total } \\
\text { dissolved solids } \\
\text { (TDS) }\end{array}$ & $\begin{array}{l}\text { - ULPRO is a system with an operating pressure of } \\
1.05 \mathrm{MPa} \text { with a feed flow rate of } 1.2 \mathrm{~m} 3 / \mathrm{h} \text {. } \\
\text { - The system removed } 98.6 \% \text { fluoride and } 96.4 \% \mathrm{TDS} \text {, } \\
\text { with } 55 \% \text { water recovery. } \\
\text { - After appropriate flocculation sedimentation (FS) pre- } \\
\text { treatment, higher removal of dissolved ions was } \\
\text { observed. } \\
\text { - Average sodium adsorption ratio (SAR) values were } \\
\text { decreased from } 81.1 \text { to } 7.2 \text { mmol0.5/L0.5. } \\
\text { - Thersystem was noted as flexible and eco-friendly, but } \\
\text { it showed several difficulties in a decentralized system. } \\
\text { This occurs as wastewater collection process by } \\
\text { pipeline from various wells might contain small } \\
\text { amount of CBM water, especially in mountainous } \\
\text { areas. Hence, further decontamination will become a } \\
\text { costly affair. }\end{array}$ & [63] \\
\hline 16. & $\begin{array}{l}\text { Reverse osmosis technique with SWHR } \\
\text { and BW-30 FILMTEC membranes }\end{array}$ & $\begin{array}{l}\text { Arsenic (As(III), } \\
\text { As }(V))\end{array}$ & $\begin{array}{l}\text { - Experimental results indicated that arsenic removal by } \\
\text { SWHR membrane was higher compared to that of the } \\
\text { BW-30 membrane. } \\
\text { pH and operating pressure have significant effect on } \\
\text { removal of } \mathrm{As}(\mathrm{V}) \text { and } \mathrm{As}(\mathrm{III}) \text {, while it remained } \\
\text { unchanged by feed water concentration. } \\
\text { - It was observed that RO operation with these } \\
\text { membranes is safe at highly basic conditions }(\mathrm{pH} \approx 11) \text {. } \\
\text { It is because of non-requirement of anti-scalants in } \\
\text { many situations }\end{array}$ & [64] \\
\hline
\end{tabular}




\begin{tabular}{|c|c|c|c|c|}
\hline 18. & $\begin{array}{l}\text { Nanofiltration using commercial thin- } \\
\text { film composite (TFC) membranes (DS-5- } \\
\text { DL, DS-51-HL and SR-1) }\end{array}$ & Fluoride & $\begin{array}{l}\text { - Experimental results indicated that rejection of fluoride } \\
\text { and solute flux increases with pressure. }\end{array}$ & [65] \\
\hline 19. & $\begin{array}{l}\text { Flat sheet cross-flow nanofiltration } \\
\text { membrane }\end{array}$ & Fluoride & $\begin{array}{l}\text { - Effect of pressure drop, crossflow rate, concentration of } \\
\text { fluoride and } \mathrm{pH} \text { on membrane charge density, solute } \\
\text { rejection and solvent flux were investigated. } \\
\text { - Results showed } 98 \% \text { removal effectiveness with a } \\
\text { yielding flux of } 158 \mathrm{~L} / \mathrm{m}^{2} . \mathrm{h} \text { at } \mathrm{pH} \text { of } 10.01 \text {. }\end{array}$ & [66] \\
\hline 22. & $\begin{array}{l}\text { Nanofiltration using commercial NE-90 } \\
\text { membrane }\end{array}$ & Arsenic & $\begin{array}{l}\text { - The effect of molecular weight cut-off (MWCO), } \\
\text { electro-kinetic charge, feed concentration and } \\
\text { individual salts rejection (NE-90) were examined in } \\
\text { detail. } \\
\text { - Results indicated that removal of arsenic from aqueous } \\
\text { solutions containing coexisting ions such as chloride, } \\
\text { sodium, sulphate and bicarbonate, was governed by } \\
\text { steric exclusion. } \\
\text { - Separation of both monovalent and bivalent As(V) } \\
\text { species was enhanced in presence of more mobile ions } \\
\text { including chloride and bicarbonate, while separation of } \\
\text { monovalent arsenate reduced in presence of a less } \\
\text { mobile ion (i.e., sulphate) due to mutual interaction } \\
\text { between them. }\end{array}$ & [67] \\
\hline 23. & $\begin{array}{l}\text { Nanofiltration using a commercial thin- } \\
\text { film composite (TFC) membrane of } \\
\text { polyamide }\end{array}$ & Arsenic & $\begin{array}{l}\text { - Result demonstrated that As(V) removal by NF with } \\
99.8 \% \text { rejection along with TDS and other } \\
\text { contaminants were achieved. } \\
\text { - Significant permeate flux was retained at the end of } \\
\text { each NF experiment with an operation time of } 180 \\
\text { minutes, thereby suggesting fouling was insignificant } \\
\text { during the process. }\end{array}$ & [68] \\
\hline
\end{tabular}




\begin{tabular}{|c|c|c|c|c|}
\hline & & & $\begin{array}{l}\text { - However, process effectiveness was dependant on } \mathrm{pH} \text {. } \\
\text { Studies were conducted between } \mathrm{pH} \text { ranging from 2-10 } \\
\text { and maximum removal occurred at } \mathrm{pH} \text {. } \\
\text { - In this study, turbidity was decreased substantially from } \\
331 \mathrm{mg} / \mathrm{L} \text { to } 102 \mathrm{mg} / \mathrm{L} \text { to produce potable water from } \\
\text { synthetic solution. }\end{array}$ & \\
\hline 24. & Electro-dialysis & Fluoride & $\begin{array}{l}\text { - The effect of experimental parameters, such as, applied } \\
\text { voltage, feed flow rate, inlet concentration and } \\
\text { dissolved anions (sulphate and chloride) on fluoride } \\
\text { removal efficiency was investigated. } \\
\text { - It was observed from the results that separation } \\
\text { performance increased when the inlet concentration of } \\
\text { fluoride in synthetic feed and was independent of feed } \\
\text { flow rate. } \\
\text { Operating time for fluoride removal became shorter } \\
\text { when applied potential was increased in the } \\
\text { experiments. } \\
\text { - Separation of fluoride was influenced by chloride ions } \\
\text { compared to sulphate ions. One reason for this } \\
\text { phenomena was steric hindrance which was higher for } \\
\text { chloride than sulphate. Another reason can be due to } \\
\text { selectivity of both cationic and anionic membrane } \\
\text { materials towards retention of divalent ions. }\end{array}$ & [69] \\
\hline 25. & $\begin{array}{l}\text { Electrodialysis with SB-6407 anion } \\
\text { exchange membrane }\end{array}$ & Fluoride & $\begin{array}{l}\text { - An optimum pH } 6 \text { was attained under the Donnan } \\
\text { dialysis condition. Maximum fluoride removal was } \\
\text { obtained in absence of mono and bivalent ions, while } \\
\text { sulphate hindered the uptake more than chloride ions. } \\
\text { - The mobility of fluoride ions enhanced as the current } \\
\text { density and feed concentration increased. } \\
\text { Electrodialysis was carried out on real water containing }\end{array}$ & [70] \\
\hline
\end{tabular}




\begin{tabular}{|c|c|c|c|c|}
\hline & & & $\begin{array}{l}21 \mathrm{mg} / \mathrm{L} \text { fluoride and removal efficiency of } 96 \% \text { was } \\
\text { achieved. }\end{array}$ & \\
\hline 26. & Electrodialysis & Fluoride & $\begin{array}{l}\text { - Operational factors affecting the treatment } \\
\text { performance such as } \mathrm{pH} \text {, current intensity and initial } \\
\text { pollutant concentration were varied. } \\
\text { - Obtained results showed that fluoride and nitrate ions } \\
\text { were removed efficiently for treatment time of six } \\
\text { minutes. } \\
\text { - Operating times for uptake of both ions became shorter, } \\
\text { when applied eurrent intensity was increased. } \\
\text { - Competition between fluoride and nitrate ions indicated } \\
\text { that nitrate ions in the solution, delayed treatment time } \\
\text { from } 7 \text { to } 20 \text { minutes. This is because of preferential } \\
\text { uptake of nitrate by the prepared membrane over } \\
\text { fluoride. }\end{array}$ & [71] \\
\hline 27. & Electrodialysis & Arsenic & $\begin{array}{l}\text { - This was investigated, using three different well waters, } \\
\text { by laboratory-scale electrodialyzer (model EUR2, } \\
\text { Eurodia Industrie SA, Wissous, France) } \\
\text { - These streams were observed to have different } \\
\text { physicochemical properties including pH, electric } \\
\text { conductivity, coexisting ions, and feed concentration. } \\
\text { - They were primarily subjected to limiting current tests. } \\
\text { It was observed that arsenic removal by electro-dialysis } \\
\text { is a non-selective process as the removal percentage } \\
\text { obtained was about } 71 \% \text { of the desalination degree } \\
\text { (DD) at the end of batch desalination. } \\
\text { - Also, specific energy consumption was observed to be } \\
\text { linearly related to DD. }\end{array}$ & {$[72]$} \\
\hline
\end{tabular}




\begin{tabular}{|c|c|c|c|c|}
\hline 28. & Electrodialysis using BEL-500 stack & Arsenic & $\begin{array}{l}\text { - Solution } \mathrm{pH} \text { and applied voltage were varied to } \\
\text { understand removal and deposition mechanism in the } \\
\text { relatively complex water. } \\
\text { - It was evident from the results that removal of inorganic } \\
\text { trace contaminants (e.g., As(V), boron, lithium, } \\
\text { selenium and uranium) increased with applied voltage. } \\
\text { - At high pH, it was observed that complexation with } \\
\text { other contaminants and precipitation of insoluble } \\
\text { species resulted in membrane scaling. } \\
\text { - Elevated stack resistance was observed with a lower } \\
\text { percentage of TDS removal, thereby affecting the } \\
\text { system performance. } \\
\text { - Hydrated radius and strength of hydration shells played } \\
\text { a less important role in transport and removal of ions } \\
\text { during electrodialysis of real water, compared to ion } \\
\text { concentration and solution pH. }\end{array}$ & [73] \\
\hline
\end{tabular}


Table 2. Different adsorbents for fluoride and arsenic uptake

\begin{tabular}{|c|c|c|c|c|c|c|}
\hline S.No. & Adsorbent & Adsorbate & $\begin{array}{l}\text { Surface } \\
\text { area } \\
\left(\mathrm{m}^{2} / \mathrm{g}\right)\end{array}$ & $\begin{array}{l}\text { Max. } \\
\text { Adsorption } \\
\text { capacity } \\
(\mathrm{mg} / \mathrm{g})\end{array}$ & Major observations & Reference \\
\hline 1. & $\begin{array}{l}\text { Magnesium oxide } \\
(\mathrm{MgO}) \text { nanoplates }\end{array}$ & Fluoride & 47 & 186 & $\begin{array}{l}\text { - Presence of carbonate, bicarbonate and } \\
\text { phosphate can influence the fluoride adsorption } \\
\text { performance } \\
\text { - Both the hydroxyl and surface carbonates can } \\
\text { exchange with fluoride ions, revealing a } \\
\text { hydroxyl and carbonate co-exchange } \\
\text { mechanism. } \\
\text { The as-prepared porous MgO nanoplates is quite } \\
\text { stable, only less than } 0.18 \% \text { of the absorbent was } \\
\text { dissolved during the adsorption experiment. }\end{array}$ & {$[76]$} \\
\hline 2. & $\begin{array}{l}\text { Zirconium oxide } \\
\text { ( } \mathrm{ZrO} 2) \text { mesoporous } \\
\text { fibers }\end{array}$ & Fluoride & 142 & & $\begin{array}{l}\text { - The surface change of the adsorbent which was } \\
\text { intensely influenced by the } \mathrm{pH} \text { value played an } \\
\text { essential role in the interaction between } \\
\text { adsorbents and fluoride } \\
\text { - Adsorption capacity was significantly influenced } \\
\text { by the co-existence of bicarbonate }\left(\mathrm{HCO}_{3}{ }^{-}\right) \text {, } \\
\text { silicate }\left(\mathrm{SiO}_{3}{ }^{2-}\right) \text { and phosphate }\left(\mathrm{PO}_{4}{ }^{3-}\right) \\
\text { - Fluoride adsorption mechanism for nanofibers } \\
\text { was an ion-exchange mechanism }\end{array}$ & {$[77]$} \\
\hline 3. & $\begin{array}{l}\text { Wheat straw raw } \\
\text { (WSR), Sawdust raw }\end{array}$ & Fluoride & - & $\begin{array}{l}\text { WSR }-2 \\
\text { SDR }-1.73 \\
A B C-1.2\end{array}$ & $\begin{array}{l}\text { - Significant amount fluoride can be achieved in } \\
\text { the neutral } \mathrm{pH} \text { range by using of these adsorbents }\end{array}$ & {$[78]$} \\
\hline
\end{tabular}




\begin{tabular}{|c|c|c|c|c|c|c|}
\hline & $\begin{array}{l}\text { (SDR) and Activated } \\
\text { bagasse carbon }(\mathrm{ABC})\end{array}$ & & & & $\begin{array}{l}\text { - Presence of other ions in groundwater did not } \\
\text { significantly affect the defluoridation process } \\
\text { - Comparison of these adsorbents with commercial } \\
\text { activated carbon reveals that these adsorbents are } \\
\text { economically viable for the removal of fluoride. }\end{array}$ & \\
\hline 4. & $\begin{array}{l}\text { Pine wood char and } \\
\text { pine bark char }\end{array}$ & Fluoride & $\begin{array}{l}\text { Pine } \\
\text { wood } \\
\text { char }-2.7 \\
\text { Pine bark } \\
\text { char }-1.9\end{array}$ & $\begin{array}{l}\text { Pine wood } \\
\text { char }-3 \\
\text { Pine bark } \\
\text { char }-5\end{array}$ & $\begin{array}{l}\text { - The chars were used without activation and } \\
\text { successfully treated fluoride contaminated } \\
\text { groundwater at pH } 2.0 \\
\text { - The chars swelled in water due to their high } \\
\text { oxygen content, opening new internal pore } \\
\text { volume and fluoride diffused into portions of the } \\
\text { chars' subsurface solid volume promoting further } \\
\text { adsorption. } \\
\text { - Ion exchange and metal fluoride precipitation } \\
\text { were observed as modes of adsorption. } \\
\text { - It was observed that pine char, could remove } \\
\text { amounts of fluoride similar to activated carbon. }\end{array}$ & [80] \\
\hline 5. & $\begin{array}{l}\text { Activated carbon } \\
\text { from the bark of } \\
\text { Morinda tinctoria } \\
\text { coated with aluminium } \\
\text { hydroxide (AHAC) }\end{array}$ & Fluoride & po & & $\begin{array}{l}\text { Beyond neutral } \mathrm{pH} \text {, a progressive decrease in } \\
\text { fluoride removal was observed due to the } \\
\text { competition for the active sites by } \mathrm{OH}^{-} \text {ion and the } \\
\text { electrostatic repulsion of fluoride ions by the } \\
\text { negatively charged AHAC surface. } \\
\text { - Fluoride distribution on AHAC follow both } \\
\text { particle and intra particle diffusion models. }\end{array}$ & [81] \\
\hline 6. & Bone char & Fluoride & 139 & 5 & $\begin{array}{l}\text { - Fluoride was diffused due to the formation of } \\
\text { fluoridated hydroxy-apatite present in bone char }\end{array}$ & [82] \\
\hline
\end{tabular}




\begin{tabular}{|c|c|c|c|c|c|c|}
\hline & & & & & $\begin{array}{l}\text { From Raman analysis, it was observed that the heat } \\
\text { treatment can increase the degree of crystallinity of } \\
\text { bone char. }\end{array}$ & \\
\hline 7. & $\begin{array}{l}\text { Bone char (BC) from } \\
\text { pleco fish } \\
\text { (Pterygoplichthys spp.) } \\
\text { CHA - carbonised fish } \\
\text { fins } \\
\text { CHC - carbonised } \\
\text { backbone }\end{array}$ & $\begin{array}{l}\text { Fluoride } \\
\text { and } \\
\text { Cadmium } \\
(\mathrm{Cd}(\mathrm{II}))\end{array}$ & $\begin{array}{l}107 \\
(\mathrm{CHA}) \\
109 \\
(\mathrm{CHC})\end{array}$ & $\begin{array}{l}24.7 \text { (F- at } \\
\mathrm{pH}-5, \\
\text { adsorption } \\
\text { on CHA) } \\
213(\mathrm{Cd}(\mathrm{II}) \\
\text { at } \mathrm{pH}-7, \\
\text { adsorption } \\
\text { on CHA) }\end{array}$ & $\begin{array}{l}\text { - CHA sample presented the highest fluoride and } \\
\text { Cd(II) adsorption capacity } \\
\text { - The effect of solution pH on the adsorption } \\
\text { capacity can be explained based on the } \\
\text { electrostatic interactions between the surface } \\
\text { charge of the CHA and the fluoride anions or } \\
\text { Cd(II) cations in solution } \\
\text { - At pH below pHpzc, the electrostatic attractions } \\
\text { played a significant role in the adsorption of } \\
\text { fluoride while the adsorption of Cd(II) is } \\
\text { promoted by electrostatic at pH higher than the } \\
\text { pHPzC when the surface of the CHA is negatively } \\
\text { charged. }\end{array}$ & [83] \\
\hline 8. & $\begin{array}{l}\mathrm{AC}-\mathrm{M} \text {, where } \mathrm{M}=\mathrm{Al} \text {, } \\
\mathrm{Fe}, \mathrm{Ce}\end{array}$ & Fluoride & - & & $\begin{array}{l}\text { - A significant reduction in fluoride sorption } \\
\text { capacity was observed for all the composites } \\
\text { treated at } 600^{\circ} \mathrm{C} \text {, due to the formation of } \\
\text { irreversible metal oxides on surface } \\
\text { - Intra-particle diffusion and boundary layer } \\
\text { diffusion were found to be the rate limiting } \\
\text { factors. } \\
\text { - Decrease in fluoride removal at higher } \mathrm{pH}(>8) \\
\text { was attributed to combined effect of both } \\
\text { competition between hydroxyl }\left(\mathrm{OH}^{-}\right) \text {and } \mathrm{F}^{-} \text {ions } \\
\text { for sorption-active sites as well as a reduction in } \\
\text { surface charge at high } \mathrm{pH}\end{array}$ & [84] \\
\hline
\end{tabular}




\begin{tabular}{|c|c|c|c|c|c|c|}
\hline & & & & & $\begin{array}{l}\text { - Based on the performances, the composites are } \\
\text { ranked as } \mathrm{AC}-\mathrm{Ce}>\mathrm{AC}-\mathrm{AlCe}>\mathrm{AC}-\mathrm{CeFe}>\mathrm{AC}- \\
\mathrm{AlCeFe}>\mathrm{AC}-\mathrm{AlFe}\end{array}$ & \\
\hline 9. & $\begin{array}{l}\text { Activated carbon from } \\
\text { rice husk }(\mathrm{ACRH})\end{array}$ & Fluoride & - & - & $\begin{array}{l}\text { - The breakthrough time decreased with } \\
\text { increasing flow rate while it increased with } \\
\text { increasing bed height. } \\
\text { - The optimum conditions were found to be initial } \\
\text { fluoride concentration of } 50 \mathrm{~m} \mathrm{~L} \mathrm{~L}^{-1} \text {, flow rate of } \\
10 \mathrm{mP} \mathrm{min}^{-1} \text { and bed height of } 3 \mathrm{~cm} \text {. } \\
\text { The Chighest activation temperature leads to the } \\
\text { lowest amount of acidic groups. }\end{array}$ & {$[85]$} \\
\hline 10. & $\begin{array}{l}\text { Activated carbon from } \\
\text { bael shell (ACBS) }\end{array}$ & Fluoride & 2 & $2.5 \mathrm{mg} / \mathrm{g}$ for & $\begin{array}{l}\text { Electrostatic attraction exists b/w the positively } \\
\text { charged surface of ACBS and anionic fluoride } \\
\text { - ACBS was able to reduce } 48.8 \% \text { of fluoride in } \\
\text { the field sample } \\
\text { - Since the fluoride removal efficiency of ACBS } \\
\text { is less, it could be used in pre-treatment in } \\
\text { combination with an ion exchange technique } \\
\text { reducing the column regeneration and operating } \\
\text { costs }\end{array}$ & [86] \\
\hline
\end{tabular}




\begin{tabular}{|c|c|c|c|c|c|c|}
\hline 11. & $\begin{array}{l}\text { Activated carbon } \\
\text { derived from calcium } \\
\text { chloride modified } \\
\text { Crocus sativus leaves } \\
\text { (AC-CMCSL) }\end{array}$ & Fluoride & - & 2 & $\begin{array}{l}\text { - The reduction of the amount of fluoride } \\
\text { adsorbed in alkaline } \mathrm{pH} \text { is due to competition } \\
\text { between hydroxyl ions and fluoride ions on } \\
\text { active sites } \\
\text { - Co-existing anions of phosphate followed by } \\
\text { sulphate, chloride and nitrate decreased fluoride } \\
\text { removal efficiency, i.e., in the following order: } \\
\mathrm{PO}_{4}{ }^{3-}>\mathrm{SO}_{4}{ }^{2-}>\mathrm{Cl}^{-}>\mathrm{NO}_{3}{ }^{-} \text {. }\end{array}$ & [87] \\
\hline 12. & $\begin{array}{l}\mathrm{Mg}-\mathrm{Mn}-\mathrm{Zr} \\
\text { impregnated activated } \\
\text { carbon }\end{array}$ & Fluoride & 834 & $p^{r}$ & $\begin{array}{l}\text { - Under the ultrasonic cavitation phenomena, } \\
\text { hydrolysis of the metal salt takes place forming } \\
\text { metat hydroxide and carbonate that help in } \\
\text { combining with fluoride ions }\left(\mathrm{F}^{-}\right) \text {by replacing } \\
\text { the }-\mathrm{OH} \text { or }-\mathrm{CO}_{3} \text { groups } \\
\text { Below pH of } 11.9 \text {, the surface is positively } \\
\text { charged and favourable fluoride adsorption } \\
\text { takes place by electrostatic force of attraction }\end{array}$ & [88] \\
\hline 13. & $\begin{array}{l}\text { Cerium impregnated } \\
\text { activated carbon-based } \\
\text { novel composite }\end{array}$ & Fluoride & - & $e^{9.9}$ & $\begin{array}{l}\text { - PCA analysis reveals that the high } \mathrm{F}^{-} \\
\text {concentration is associated with high } \mathrm{pH} \text {, } \\
\text { alkalinity and } \mathrm{Na}^{+} \text {concentration. } \\
\text { - The presence of high alkalinity and } \mathrm{pH} \text { in the } \\
\text { groundwater resulted in a reduction in the } \\
\text { performance of the composite for } \mathrm{F}^{-} \text {removal }\end{array}$ & [89] \\
\hline 14. & Feldspar & Arsenic & $\begin{array}{c}0.65- \\
1.7\end{array}$ & $\begin{array}{c}0.0059- \\
0.0205\end{array}$ & $\begin{array}{l}\text { - Arsenic (V) uptake was observed to decrease at } \\
\text { the pHPZC values of the sorbents } \\
\text { - On the contrary, both positively charged surface } \\
\text { of solid i.e. aluminol active sites and } \\
\text { predominant speciation of } \mathrm{H}_{2} \mathrm{AsO}_{4}^{-} \text {are } \\
\text { favourable for } \mathrm{As}(\mathrm{V}) \text { uptake at acidic condition. }\end{array}$ & [90] \\
\hline
\end{tabular}




\begin{tabular}{|c|c|c|c|c|c|c|}
\hline & & & & & $\begin{array}{l}\text { However, adsorption of monodentate non- } \\
\text { ionized arsenite }(\mathrm{As}(\mathrm{III})) \text { was contrary to As (V) } \\
\text { as it occurred only through a ligand exchange } \\
\text { reaction } \\
\text { - Coulombic interaction and solution pH is } \\
\text { practically insignificant for As(III) adsorption as } \\
\text { compared to } \mathrm{As}(\mathrm{V}) \text {. }\end{array}$ & \\
\hline 15. & $\begin{array}{l}\text { Iron oxide modified } \\
\text { thermally produced } \\
\text { cigarette soot activated } \\
\text { carbon }\left(\mathrm{Fe}_{3} \mathrm{O}_{4} / \mathrm{CSAC}\right)\end{array}$ & Arsenic & 576 & $\begin{array}{l}81 \mathrm{As}(\mathrm{III}) \\
108 \mathrm{As}(\mathrm{V})\end{array}$ & $\begin{array}{l}\text { - Hydroxyl groups on adsorbent surface were } \\
\text { removed by arsenic species, which includes a } \\
\text { complex mechanism of monodentate and } \\
\text { bidentate ligand exchange mechanism. } \\
\text { - As(V) was adsorbed by both electrostatic } \\
\text { attraction and the monodentate and bidentate } \\
\text { complex formation } \\
\text { - As(III) was adsorbed only due to monodentate } \\
\text { complex formation. }\end{array}$ & [91] \\
\hline 16. & Magnetic biochar & Arsenic & - & $\mathrm{e}^{\mathrm{O}}$ & $\begin{array}{l}\text { Relative fast kinetics suggested that biochar } \\
\text { might play an important role in the dispersion of } \\
\gamma-\mathrm{Fe}_{2} \mathrm{O}_{3} \text { particles, which efficiently increased } \\
\text { the surface area of particles and active sites of } \\
\text { metal oxides. } \\
\text { - Kinetic study also suggested that adsorption of } \\
\mathrm{As}(\mathrm{V}) \text { to metal oxide surfaces is mainly through } \\
\text { surface complexation reactions and can be } \\
\text { described by one and two-site models. }\end{array}$ & [92] \\
\hline 17. & $\begin{array}{l}\text { Iron loaded activated } \\
\text { carbon (FCAC) }\end{array}$ & Arsenic & 1266 & 1.3 & $\begin{array}{l}\text { - } \mathrm{pH} \text { controls the surface functionality of FCAC } \\
\text { - Higher number of organic functional groups was } \\
\text { predicted to be randomly distributed on the }\end{array}$ & [93] \\
\hline
\end{tabular}




\begin{tabular}{|c|c|c|c|c|c|c|}
\hline & & & & & $\begin{array}{l}\text { chemical activated carbon (CAC) surface than } \\
\text { that of physical activated carbon (PAC) } \\
\text { - } \mathrm{CAC} \text { adsorbed iron species acted as amorphous } \\
\mathrm{Fe}_{3} \mathrm{O}_{4} \text { on the micropore surface, thereby } \\
\text { narrowing down pore size } \\
\text { - FCAC could achieve the desired uptake of } \\
\text { arsenic due to iron, which has strong affinity to } \\
\text { surface functional groups and arsenic species. }\end{array}$ & \\
\hline 18. & $\begin{array}{l}\text { Sargassum muticum } \\
\text { coated with iron- } \\
\text { oxy(hydroxides) }\end{array}$ & Arsenic & - & $\begin{array}{l}4(\mathrm{As}(\mathrm{III})) \\
7(\mathrm{As}(\mathrm{V}))\end{array}$ & $\begin{array}{l}\text { - Predominant arsenate uptake mechanism is } \\
\text { adsorption on iron sites, based on the formation } \\
\text { of monodentate and bidentate species }\end{array}$ & [94] \\
\hline 19. & $\begin{array}{l}\text { Iron hydroxide/ } \\
\text { manganese dioxide } \\
\text { doped straw activated } \\
\text { carbon (Fe-Mn-SAc) }\end{array}$ & $\begin{array}{l}\text { Arsenic } \\
(\mathrm{As}(\mathrm{III}))\end{array}$ & 508 & 76 & $\begin{array}{l}\text { - Part of the } \mathrm{As}(\mathrm{III}) \text { in aqueous solutions was } \\
\text { oxidized into } \mathrm{As}(\mathrm{V}) \text { by } \mathrm{MnO}_{2} \text { and then adsorbed } \\
\text { on the surface of } \mathrm{Fe}-\mathrm{Mn}-\mathrm{SAc} \text {, and chelation } \\
\text { reaction with - } \mathrm{COOH} \text { on the } \mathrm{SAc} \text { and/or iron } \\
\text { oxide surface seemed to be another important } \\
\text { mechanism in } \mathrm{As}(\mathrm{III}) \text { adsorption because no } \\
\mathrm{H}_{3} \mathrm{AsO}_{3} \text { was ionized under this acidic condition. } \\
\mathrm{Moreover} \text { due to the oxidation of } \mathrm{As}(\mathrm{III}) \text { by } \\
\mathrm{MnO}_{2} \text {, surface alterations occurred and fresh } \\
\text { reaction sites (FeOOH) were created in this } \\
\text { process, which favored the adsorption of } \\
\text { generated As(V). } \\
\text { Slower arsenic adsorption kinetics suggests that } \\
\text { the adsorption process involved surfaces } \\
\text { adsorption stage controlling by pore diffusion } \\
\text { and inter adsorption stage governing by the }\end{array}$ & [95] \\
\hline
\end{tabular}




\begin{tabular}{|c|c|c|c|c|c|c|}
\hline & & & & & $\begin{array}{l}\text { intraparticle diffusion in the pore structure } \\
\text { between arsenic and active carbon }\end{array}$ & \\
\hline 20. & $\begin{array}{l}\text { Perilla leaf biochar } \\
(\mathrm{BC} 300 \text { and } \mathrm{BC} 700)\end{array}$ & Arsenic & $\begin{array}{l}3 \text { for } \\
\text { (BC300) } \\
473 \text { for } \\
\text { (BC700) }\end{array}$ & $\begin{array}{l}11 \mathrm{mg} / \mathrm{g} \\
(\mathrm{As}(\mathrm{III})- \\
\mathrm{BC} 700) \\
7 \mathrm{mg} / \mathrm{g} \\
(\mathrm{As}(\mathrm{V})- \\
\mathrm{BC} 700)\end{array}$ & $\begin{array}{l}\text { - A large difference in specific surface area } \\
\text { between the two biochars is attributed to } \\
\text { production of tars during biomass thermal } \\
\text { decomposition, which could either prevent } \\
\text { formation of pores or impede continuity of pores } \\
\text { at low temperature (i.e., BC300), while at high } \\
\text { temperature (i.e., BC700), these pores become } \\
\text { easily accessible due to volatilization of tar } \\
\text { components } \\
\text { A decline in As(V) sorption in an alkaline pH } \\
\text { range on the surface of BC300 and BC700 could } \\
\text { be due to abundance and competition of } \\
\text { negatively charged hydroxyl (OH) ions with } \\
\text { As(V) oxyanions for the available sorption sites } \\
\text { Higher As(V) and As(III) sorption in acidic pH } \\
\text { range for BC300 could be ascribed to reduced } \\
\text { aromaticity and higher surface polarity, and as } \\
\text { such significantly more number of acidic } \\
\text { functional groups on its surface than that of } \\
\text { BC700, thereby enhancing As oxyanions } \\
\text { binding (electrostatic attraction) with positively } \\
\text { charged biochar (BC300) surface } \\
\text { Both monolayer sorption and micro-pore filling } \\
\text { were dominant mechanisms for As removal }\end{array}$ & [96] \\
\hline 21. & $\begin{array}{l}\text { Japanese oak wood } \\
\text { biochar (OW-BC) }\end{array}$ & Arsenic & 475 & $\begin{array}{l}4 \mathrm{mg} / \mathrm{g} \\
(\operatorname{As}(\mathrm{V}))\end{array}$ & $\begin{array}{l}\text { - Langmuir model efficiently described } \mathrm{As}(\mathrm{III}) \\
\text { and } \mathrm{As}(\mathrm{V}) \text { sorption to the surface of } \mathrm{OW}-\mathrm{BC} \text {, }\end{array}$ & [97] \\
\hline
\end{tabular}




\begin{tabular}{|c|c|c|c|c|c|c|}
\hline & & & & $\begin{array}{l}3 \mathrm{mg} / \mathrm{g} \\
(\mathrm{As}(\mathrm{III}))\end{array}$ & $\begin{array}{l}\text { which may suggest that monolayer sorption and } \\
\text { precipitation is a dominant mechanism for both } \\
\text { As species removal in aqueous solutions. } \\
\text { - Relatively, higher } \mathrm{As}(\mathrm{V}) \text { sorption in acidic } \mathrm{pH} \\
\text { range by OW-BC is due to abundance of } \\
\text { positively charged sites and as well as } \\
\text { protonation of functional groups on biochar } \\
\text { surface, thereby enhancing As oxyanions } \\
\text { binding via electrostatic attraction } \\
\text { - A decline in As }(\mathrm{V}) \text { sorption, particularly in an } \\
\text { alkaline pH range, on the surface of OW-BC is } \\
\text { due to the abundance and increasing competition } \\
\text { of negatively charged hydroxyl }\left(\mathrm{OH}^{-}\right) \text {ions with } \\
\text { As(V) oxyanions for the available sorption sites }\end{array}$ & \\
\hline 22. & $\begin{array}{l}\text { Cerium oxide modified } \\
\text { activated carbon }\end{array}$ & Arsenic & 414 & $\begin{array}{l}43 \mathrm{mg}-\mathrm{As} / \mathrm{g}) \\
(\mathrm{As}(\mathrm{V}) \\
33 \mathrm{mg}-\mathrm{As} / \mathrm{g} \\
(\mathrm{As}(\mathrm{III}))\end{array}$ & $\begin{array}{l}\text { The adsorption kinetics of } \mathrm{As}(\mathrm{V}) \text { and } \mathrm{As}(\mathrm{III}) \text { can } \\
\text { be well fitted by the intraparticle pore diffusion } \\
\text { model. } \\
\text { - A stronger electrostatic repulsion }(\mathrm{pH}>6) \text { would } \\
\text { be formed between the adsorbent and } \mathrm{As}(\mathrm{V}) \text {. } \\
\text { This may be the reason that a relatively higher } \\
\text { uptake of As(III) is achieved than } \mathrm{As}(\mathrm{V}) \text { at such } \\
\mathrm{pH} \text { values } \\
\text { - The ligand exchange between hydroxyl groups } \\
\text { formed on the surface of cerium oxide and } \\
\text { arsenic species is likely responsible for the } \\
\text { arsenic removal } \\
\text { At high solution pH, deprotonation of hydroxyl } \\
\text { groups results in stronger electrostatic repulsion }\end{array}$ & [98] \\
\hline
\end{tabular}




\begin{tabular}{|c|c|c|c|c|c|c|}
\hline & & & & & $\begin{array}{l}\text { between the adsorbent and arsenic, which would } \\
\text { affect the diffusion of arsenic towards the } \\
\text { adsorption sites on the adsorbent and finally } \\
\text { cause a more significant influence on the } \\
\text { removal of } \mathrm{As}(\mathrm{V}) \text { than } \mathrm{As}(\mathrm{III}) \text {. }\end{array}$ & \\
\hline 23. & $\begin{array}{l}\mathrm{CeO}_{2} / \mathrm{Fe}_{2} \mathrm{O}_{3} / \text { graphene } \\
\text { nanocomposite }\end{array}$ & Arsenic & 228 & $\begin{array}{l}101 \mathrm{mg} / \mathrm{g} \\
(\mathrm{As}(\mathrm{III}) \\
84 \mathrm{mg} / \mathrm{g} \\
(\mathrm{As}(\mathrm{V}))\end{array}$ & $\begin{array}{l}\text { - The }-\mathrm{OH} \text { groups of adsorbate and adsorbent } \\
\text { were responsible for adsorption. } \\
\text { - At lower } \mathrm{pH} \text {, the surface hydroxyl groups were } \\
\text { protonated which did not participate in } \mathrm{As}(\mathrm{III}) \\
\text { adsorption and with an increase in } \mathrm{pH} \text { adsorption } \\
\text { occurred and with further increase repulsion } \\
\text { took place between the } \mathrm{OH} \text { - and negatively } \\
\text { charged arsenite ions. } \\
\text { At lower pH, electrostatic attraction took place } \\
\text { between the positive surface charge of adsorbent } \\
\text { and negative charge of } \mathrm{H}_{2} \mathrm{AsO}_{4} \text {. But with an } \\
\text { increase in pH, the repulsion arises between } \mathrm{OH}- \\
\text { ions and the negatively charged } \mathrm{HAsO}_{4} \text {-and } \\
\mathrm{AsO}_{4}{ }^{3-} \text { ions, which tends to decrease the } \mathrm{As}(\mathrm{V}) \\
\text { removal. }\end{array}$ & [99] \\
\hline 24. & $\begin{array}{l}\text { Halloysite- } \mathrm{CeO}_{\mathrm{x}}(\mathrm{x}= \\
1.5-2.0) \\
\text { nanocomposite }\end{array}$ & $\begin{array}{l}\text { Arsenic } \\
(\mathrm{As}(\mathrm{III}))\end{array}$ & 91 & 209 & $\begin{array}{l}\text { - The modification of halloysite using a facile } \\
\mathrm{NaOH} \text { treatment increased the inner-surface and } \\
\text { inner hydroxyl groups that enhanced the } \\
\text { dispersion of the coating of } \mathrm{CeO}_{2} \text { nanoparticles } \\
\text { due to electrostatic interactions. } \\
\text { - The As(III) adsorption mechanisms on this } \\
\text { composite involved the formation of surface }\end{array}$ & [100] \\
\hline
\end{tabular}




\begin{tabular}{|c|c|c|c|c|c|c|}
\hline & & & & & $\begin{array}{l}\text { complexes and oxidation of partial As(III) } \\
\text { followed by } \mathrm{As}(\mathrm{V}) \text { adsorption. }\end{array}$ & \\
\hline 25. & $\begin{array}{l}\text { Magnetic gelatin } \\
\text { modified biochar (MG- } \\
\text { SCB) }\end{array}$ & $\begin{array}{l}\text { Arsenic } \\
(\operatorname{As}(V))\end{array}$ & - & 46 & $\begin{array}{l}\text { - Chemisorption of } \mathrm{As}(\mathrm{V}) \text { was the rate- } \\
\text { determining step of adsorption process, which } \\
\text { involved the chemical interaction between } \\
\text { arsenic }(\mathrm{V}) \text { ions and polar functional groups on } \\
\text { the adsorbent, such as ion exchange and } \\
\text { chelating reaction } \\
\text { - The sorption of As }(\mathrm{V}) \text { onto MG-CSB could be } \\
\text { controlled by multiple processes associated with } \\
\text { both oxygen and iron oxide surfaces. } \\
\text { Both electrostatic interaction and hydroxyl } \\
\text { complexation between As }(\mathrm{V}) \text { and MG-CSB } \\
\text { contributed to the adsorption }\end{array}$ & [101] \\
\hline 26. & $\begin{array}{l}\mathrm{Fe}_{3} \mathrm{O}_{4} @ \mathrm{Al}_{2} \mathrm{O}_{3} @ \mathrm{Zn}-\mathrm{Fe} \\
\mathrm{LDH} \\
\text { (LDH - layered double } \\
\text { hydroxides) }\end{array}$ & Arsenic & 157 & & $\begin{array}{l}\text { - The adsorption of As onto the adsorbent follows } \\
\text { the Langmuir model. } \\
\text { - Alumina as a substrate causes to increase the } \\
\text { specific surface area and more value of LDH } \\
\text { could be place on the surface of alumina and } \\
\text { then maximum adsorption capacity was } \\
\text { increased. } \\
\text { - The negative hydroxyl groups in the synthesized } \\
\text { LDH adsorbent were exchanged with arsenate } \\
\text { ions and the mechanism of As removal by } \\
\text { synthesized adsorbent was ion exchange. }\end{array}$ & {$[102]$} \\
\hline 27. & $\begin{array}{l}\text { Iron-incorporated } \\
\text { activated carbon }\end{array}$ & $\begin{array}{l}\text { Arsenic } \\
(\operatorname{As}(\mathrm{V}))\end{array}$ & 375 & 43 & $\begin{array}{l}\text { - As(V) adsorption on MAC was almost } \\
\text { independent of solution } \mathrm{pH}\end{array}$ & [103] \\
\hline
\end{tabular}




\begin{tabular}{|c|c|c|c|c|c|c|}
\hline & $\begin{array}{l}\text { (MAC) from biomass } \\
\text { mixture }\end{array}$ & & & & $\begin{array}{l}\text { - The arsenic removal mechanism includes } \\
\text { mainly precipitation and surface complexation } \\
\text { i.e., chemical adsorption }\end{array}$ & \\
\hline 28. & $\begin{array}{l}\text { Mesoporous bismuth- } \\
\text { impregnated aluminum } \\
\text { oxide (BiAl) }\end{array}$ & Arsenic & 131 & 16 & $\begin{array}{l}\text { - The main mechanism was chemisorption with } \\
\text { both bismuth and aluminium atoms; however, } \\
\text { physisorption also contributed to arsenic } \\
\text { adsorption at the initial stage of the reaction. } \\
\text { - Intraparticle-diffusion, limits the adsorptive rate }\end{array}$ & [104] \\
\hline 29. & $\begin{array}{l}\text { Aluminum-based } \\
\text { adsorbent (ABA) and } \\
\text { coal mine drainage } \\
\text { sludge coated } \\
\text { polyurethane (CMDS- } \\
\text { PU) }\end{array}$ & $\begin{array}{l}\text { Arsenic } \\
(\mathrm{As}(\mathrm{V}))\end{array}$ & $\begin{array}{l}102 \mathrm{~m}^{2} / \mathrm{g} \\
(\mathrm{ABA}) \\
4.2 \mathrm{~m}^{2} / \mathrm{g} \\
(\mathrm{CMDS}- \\
\mathrm{PU})\end{array}$ & $\begin{array}{l}31 \mathrm{mg} / \mathrm{g} \\
(\mathrm{ABA}) \\
10 \mathrm{mg} / \mathrm{g} \\
(\mathrm{CMDS}- \\
\text { PU) }\end{array}$ & $\begin{array}{l}\text { - As }(\mathrm{V}) \text { adsorption using CMDS-PU was found to } \\
\text { be unfavourable } \\
\text { - The } A s(V) \text { adsorption kinetics onto ABA and } \\
\text { CMDS-PU followed a pseudo-second order rate } \\
\text { equation. } \\
\text { - Application of the intraparticle diffusion model } \\
\text { revealed the adsorption process to be complex. } \\
\text { High pH negatively influenced the adsorption } \\
\text { capacity of ABA and CMDS-PU. }\end{array}$ & [105] \\
\hline 30. & $\begin{array}{l}\text { Covalent } \\
\text { triazine framework } \\
\text { encapsulated } \gamma-\mathrm{Fe}_{2} \mathrm{O}_{3} \\
\text { nanoparticles }\end{array}$ & $\begin{array}{l}\text { Arsenic, } \\
\text { Mercury }\end{array}$ & 1049 & $\begin{array}{l}198 \mathrm{mg} / \mathrm{g} \\
(\mathrm{As}(\mathrm{III})) \\
102 \mathrm{mg} / \mathrm{g} \\
(\mathrm{As}(\mathrm{V})) \\
166 \mathrm{mg} / \mathrm{g} \\
\mathrm{Hg}^{\mathrm{II}}\end{array}$ & $\begin{array}{l}\text { - The removal of } \mathrm{Hg} \text { decreases only at the } \mathrm{pH} \text { of } \\
\text { 11, presumably due to the formation of stable } \\
\text { hydroxide complexes, withdrawing free ions } \\
\text { from solution }\end{array}$ & [106] \\
\hline
\end{tabular}


Table 3. Different mechanisms for fluoride and arsenic uptake by MOFs

\begin{tabular}{|c|c|c|c|c|c|c|}
\hline $\begin{array}{l}\text { SI. } \\
\text { No }\end{array}$ & MOF & $\begin{array}{l}\text { Uptake } \\
\text { mechanism }\end{array}$ & $\begin{array}{l}\text { Surface } \\
\operatorname{area}\left(\mathrm{m}^{2} / \mathrm{g}\right)\end{array}$ & $\begin{array}{l}\text { Adsorption } \\
\text { capacity }(\mathrm{mg} / \mathrm{g})\end{array}$ & Contaminant & Reference \\
\hline 1. & Aluminium fumarate $\mathrm{MOF}$ & $\begin{array}{l}\text { Intra particle } \\
\text { diffusion }\end{array}$ & 1156 & 600 & Fluoride & {$[108]$} \\
\hline 2. & Zr-MOF (UiO-66) & $\begin{array}{l}\text { Electrostatic } \\
\text { interaction, } \\
\text { Coordination } \\
\text { interactions }\end{array}$ & 570 & 303 & Arsenic & [109] \\
\hline 3. & $\mathrm{UiO}-66(\mathrm{Zr})$ & $\begin{array}{l}\text { Surface adsorption } \\
\text { and intraparticle } \\
\text { diffusion }\end{array}$ & & 41 & Fluoride & {$[127]$} \\
\hline 4. & $\begin{array}{l}\text { Lanthanide based MOFs } \\
\left.\text { (1) } \mathrm{Ce}(\mathrm{L} 1)_{0.5}\left(\mathrm{NO}_{3}\right)\left(\mathrm{H}_{2} \mathrm{O}\right)_{2}\right] \cdot 2 \mathrm{DMF} \\
\text { (2) } \mathrm{Eu}_{3}(\mathrm{~L} 2)_{2}(\mathrm{OH})(\mathrm{DMF})_{0.22}\left(\mathrm{H}_{2} \mathrm{O}\right)_{5.78}\end{array}$ & $\begin{array}{l}\text { Strong } \\
\text { interaction } \\
\text { between fluoride } \\
\text { and the Ce site }\end{array}$ & - & $\begin{array}{l}\text { (1) } 104 \\
\text { (2) } 57\end{array}$ & Fluoride & {$[128]$} \\
\hline 5 . & Zr-MOF adsorbent and membrane & $\begin{array}{l}\text { Hydroxyl groups } \\
\text { bonded to } \mathrm{Zr} \\
\text { species exchanging } \\
\text { with fluoride. }\end{array}$ & 740 & 102 & Fluoride & [129] \\
\hline 6. & $\mathrm{UiO}-66-\mathrm{NH}_{2}$ & $\begin{array}{l}\text { Boundary layer } \\
\text { diffusion and intra } \\
\text { particle diffusion }\end{array}$ & 905 & 56 & Fluoride & {$[130]$} \\
\hline
\end{tabular}




\begin{tabular}{|c|c|c|c|c|c|c|}
\hline 7. & MOF -801 & Ion exchange & 725 & 40 & Fluoride & [131] \\
\hline 8. & Calcium Fumarate $(\mathrm{CaFu})$ & Ion exchange & 755 & 166 & Fluoride & [132] \\
\hline 9. & UiO-66-amine & $\begin{array}{l}\text { Adsorbate - } \\
\text { adsorbent } \\
\text { interaction }\end{array}$ & 569 & $41 \mathrm{mg} / \mathrm{L}$ & Fluoride & [133] \\
\hline 10. & $\mathrm{ZIF}-8$ & Pore diffusion & 1064 & $\begin{array}{l}\operatorname{As}(\mathrm{III})-49 \\
\mathrm{As}(\mathrm{V})-60\end{array}$ & Arsenic & [134] \\
\hline 11. & $\begin{array}{l}\mathrm{Zn}-\mathrm{MOF}-74 \\
\text { (1) } \mathrm{RT}-\mathrm{Zn}-\mathrm{MOF}-74(\mathrm{RT}- \\
\text { room temp.) } \\
\text { (2) } \mathrm{HT}-\mathrm{Zn}-\mathrm{MOF}-74(\mathrm{HT}- \\
\text { Solvothermal) }\end{array}$ & $\begin{array}{l}\text { Chemical } \\
\text { interactions and } \\
\text { Intraparticle } \\
\text { diffusion }\end{array}$ & $\begin{array}{c}(1)-690 \\
(2)-1201 \\
2\end{array}$ & $\begin{array}{l}(1)-99 \\
(2)-49\end{array}$ & Arsenic & [135] \\
\hline 12. & $\begin{array}{l}\text { AUBM-1 (AUBM = American } \\
\text { University of Beirut Materials) }\end{array}$ & $\begin{array}{l}\text { Electrostatic } \\
\text { interactions, } \\
\text { chemical acid-base } \\
\text { interactions }\end{array}$ & 310 & 103 & Arsenic & [136] \\
\hline 13. & $\mathrm{NH}_{2}-\mathrm{MIL}-88(\mathrm{Fe})$ & $\begin{array}{l}\text { Acid-Base } \\
\text { interaction }\end{array}$ & 201 & 125 & Arsenate & [137] \\
\hline 14. & MIL-53(Fe) & $\begin{array}{l}\text { Electrostatic } \\
\text { interaction, Lewis } \\
\text { acid-base } \\
\text { interactions }\end{array}$ & 14 & 21.27 & Arsenic & [138] \\
\hline
\end{tabular}




\begin{tabular}{|c|c|c|c|c|c|c|}
\hline 15. & MIL-101(OH $)_{3}$ and MIL-101(OH) & $\begin{array}{l}\text { Electrostatic } \\
\text { interaction, } \\
\text { hydrogen bonding }\end{array}$ & $\begin{array}{l}2023(\mathrm{MIL}- \\
\left.101(\mathrm{OH})_{3}\right) \\
2119(\mathrm{MIL}- \\
101-\mathrm{OH})\end{array}$ & $\begin{array}{l}139 \text { (PAA) by } \\
\left(\mathrm{MIL}-101(\mathrm{OH})_{3}\right) \\
84 \text { (PAA) by } \\
\text { (MIL-101-OH) } \\
238 \text { (ASA) by } \\
\left(\mathrm{MH}-101(\mathrm{OH})_{3}\right) \\
\text { ( } \\
163 \text { (ASA) } \\
\text { by (MIL-101- } \\
\text { OH) }\end{array}$ & $\begin{array}{l}\text { Arsenic acids } \\
\text { (PAA- } \\
\text { phenylarsonic } \\
\text { acid, ASA - p- } \\
\text { arsanilic acid) }\end{array}$ & [139] \\
\hline 16. & MOF-808 & $\begin{array}{l}\text { Electrostatic } \\
\text { interaction }\end{array}$ & - & 25 & Arsenate & [140] \\
\hline 17. & MIL-53(Al) & $\begin{array}{l}\text { Electrostatic } \\
\text { interaction }\end{array}$ & 920 & 106 & Arsenate & [141] \\
\hline 18. & ZIF-8 & $\begin{array}{l}\text { Electrostatic } \\
\text { interaction }\end{array}$ & - & 77 & Arsenate & [142] \\
\hline 19. & $\begin{array}{l}\text { UiO-66 incorporated thin } \\
\text { nanocomposite membrane }\end{array}$ & $\begin{array}{l}\text { Electrostatic } \\
\text { repulsion }\end{array}$ & - & - & $\begin{array}{l}\text { Selenium, } \\
\text { Arsenic }\end{array}$ & [143] \\
\hline 20. & $\mathrm{Fe}_{3} \mathrm{O}_{4} @ \mathrm{MIL}-101$ & Redox reaction & 2270 & $122(\mathrm{As}(\mathrm{III}))$ & Arsenic & [144] \\
\hline
\end{tabular}




\begin{tabular}{|c|l|l|c|c|c|c|}
\hline 21. & $\begin{array}{l}\text { ZIF-8 (cetyltrimethylammonium } \\
\text { bromide (CTAB) and amino } \\
\text { acid L-histidin (His) as co- } \\
\text { templates) }\end{array}$ & $\begin{array}{l}\text { Electrostatic } \\
\text { interaction }\end{array}$ & 587 & 91 & Arsenic & {$[145]$} \\
\hline 22. & BUC-17 & $\begin{array}{l}\text { Electrostatic } \\
\text { interaction, Acid- } \\
\text { base interaction }\end{array}$ & 2 & 129 & Arsenic & {$[146]$} \\
\hline
\end{tabular}


Table 4. Breakthrough time and cost analysis of MOFs for fluoride and arsenic uptake

\begin{tabular}{|c|c|c|c|c|c|}
\hline S.No & MOF type & Adsorbent & Breakthrough time (h) & $\begin{array}{l}\text { Cost (USD) } \\
\text { per gram of } \\
\text { MOF }\end{array}$ & Reference \\
\hline 1. & Aluminium fumarate MOF & Fluoride & 9 & 0.4 & {$[108]$} \\
\hline 2. & Zr-MOF (UiO-66) & Arsenic & 44 & 0.2 & [109] \\
\hline 3. & $\mathrm{UiO}-66(\mathrm{Zr})$ & Fluoride & 6 & 1 & {$[127]$} \\
\hline 4. & $\begin{array}{l}\left.\text { (1) } \mathrm{Ce}(\mathrm{L} 1)_{0.5}\left(\mathrm{NO}_{3}\right)\left(\mathrm{H}_{2} \mathrm{O}\right)_{2}\right] \cdot 2 \mathrm{DMF} \\
\text { (2) } \mathrm{Eu}_{3}(\mathrm{~L} 2)_{2}(\mathrm{OH})(\mathrm{DMF})_{0.22}\left(\mathrm{H}_{2} \mathrm{O}\right)_{5.78}\end{array}$ & Fluoride & $\begin{array}{l}(1)-16 \\
(2)-9\end{array}$ & $\begin{array}{l}(1)-1 \\
(2)-1\end{array}$ & {$[128]$} \\
\hline 5. & Zr-MOF & Fluoride & 15 & 0.1 & [129] \\
\hline 6. & $\mathrm{UiO}-66-\mathrm{NH}_{2}$ & Fluoride & 7 & 0.5 & {$[130]$} \\
\hline 7. & MOF -801 & Fluoride & 6 & 0.4 & {$[131]$} \\
\hline 8. & Calcium Fumarate $(\mathrm{CaFu})$ & Fluoride & 25 & 0.5 & [132] \\
\hline 9. & UiO-66-amine & Fluoride & 7 & 0.2 & {$[133]$} \\
\hline 10. & $\mathrm{ZIF}-8$ & Arsenic & $\begin{array}{l}\text { As (III) }-15 \\
\text { As(V) }-18\end{array}$ & 0.4 & {$[134]$} \\
\hline 11. & $\mathrm{Zn}-\mathrm{MOF}-74$ & Arsenic & As (III) -29 & 2 & {$[135]$} \\
\hline
\end{tabular}




\begin{tabular}{|c|c|c|c|c|c|}
\hline & & & As(V) -14 & & \\
\hline 12. & AUBM-1 & Arsenic & 31 & 0.6 & [136] \\
\hline 13. & $\mathrm{NH}_{2}-\mathrm{MIL}-88(\mathrm{Fe})$ & Arsenic & 37 & 0.5 & [137] \\
\hline 14. & $\mathrm{MIL}-53(\mathrm{Fe})$ & Arsenic & 6 & 0.6 & [138] \\
\hline 15. & MIL-101(OH $)_{3}$ and MIL-101(OH) & Arsenic & $\begin{array}{l}42(\mathrm{PAA}) \text { by }(\mathrm{MIL}- \\
\left.101(\mathrm{OH})_{3}\right) \\
26(\mathrm{PAA}) \text { by }(\mathrm{MIL}-101- \\
\mathrm{OH}) \\
71(\mathrm{ASA}) \text { by }(\mathrm{MIL}- \\
\left.101(\mathrm{OH})_{3}\right) \\
49(\mathrm{ASA}) \\
\text { by }(\mathrm{MIL}-101-\mathrm{OH})\end{array}$ & 2 & [139] \\
\hline 16. & MOF -808 & Arsenic & 7 & 0.3 & [140] \\
\hline 17. & MIL-53(Al) & Arsenic & 32 & 0.2 & [141] \\
\hline 18. & $\mathrm{ZIF}-8$ & Arsenic & 23 & 0.4 & [142] \\
\hline 19. & UiO-66 incorporated thin nanocomposite membrane & $\begin{array}{l}\text { Selenium, } \\
\text { Arsenic }\end{array}$ & $\begin{array}{l}\text { Rejections of } \\
96 \%-\mathrm{SeO}_{3}{ }^{2-}\end{array}$ & 5 & [143] \\
\hline
\end{tabular}




\begin{tabular}{|c|c|c|c|c|c|}
\hline & & & $\begin{array}{l}97 \%-\mathrm{SeO}_{4}{ }^{2-} \\
98 \%-\mathrm{HAsO}_{4}{ }^{2-}\end{array}$ & & \\
\hline 20. & $\mathrm{Fe}_{3} \mathrm{O}_{4} @ \mathrm{MIL}-101$ & Arsenic & $\begin{array}{l}36 \mathrm{As}(\mathrm{III}) \\
24 \mathrm{As}(\mathrm{V})\end{array}$ & 1 & [144] \\
\hline 21. & $\begin{array}{l}\text { ZIF-8 (cetyltrimethylammonium bromide (CTAB) and } \\
\text { amino acid L-histidine (His) as co-templates) }\end{array}$ & Arsenic & 27 & 2 & [145] \\
\hline 22. & $\mathrm{BUC}-17$ & Arsenic & 39 & 5 & [146] \\
\hline
\end{tabular}




\section{Supplementary Information}

for

Versatility, cost analysis, and scale-up in fluoride and arsenic removal using metal-organic framework based adsorbents

Linisha Biswal $^{\mathrm{a}}$, Joseph E. Goodwill ${ }^{\mathrm{b}}$, Christoph Janiak ${ }^{\mathrm{c}}$, Somak Chatterjee ${ }^{\mathrm{a} *}$

aDepartment of Chemical Engineering, Birla Institute of Technology and Science-Pilani, Pilani, Rajasthan, India.

${ }^{b}$ Department of Civil and Environmental Engineering, University of Rhode Island, Kingston, Rhode Island, United States of America.

'Institute of Inorganic and Structural Chemistry, Heinrich-Heine-Universität Düsseldorf, 40204 Düsseldorf, Germany.

\footnotetext{
* Corresponding author:

Tel: $+01596-51-5757$

Fax: + 91-1596-244183

Email - somak.chatterjee@pilani.bits-pilani.ac.in
} 